\title{
Kolizyjnoprawne aspekty małżeństw dzieci
}

\begin{abstract}
In the Western culture there is a widespread belief that marriage should be contracted only by freely expressed will. Hence, marriages concluded at an early age are considered unacceptable. Entering into marriage by children has a negative impact on their education, physical and mental health, as well as their socioeconomic position. For this reason, such practices are incompatible with human rights. Therefore, European countries are trying to counteract them, which results in taking specific legislative actions. The intensification of these activities is particularly evident in the last decade, which is mainly caused by the increased migration to Europe from countries belonging to other cultural circles. Child marriages, being a phenomenon strongly embedded in culture, have become one of the areas where there are frictions between the majority, which in principle determines the shape of legal regulations, and minorities who, on the one hand, want to live in European countries, but also want to preserve the traditions that are cultivated in their countries of origin.

The changes in law considering child marriages are undertaken in realm of substantive law as well as conflict of laws rules. In the second case, the states introduce specific public policy clauses referring to child marriages. The paper aims at describing and evaluating those changes in law, especially from the point of view of private international law.
\end{abstract}

Keywords: child marriage, recognition of marriage, conflict of laws, public order clause

a) Dr, Instytut Europeistyki Uniwersytet Jagielloński. 


\section{Wstęp}

W zachodnim kręgu kulturowym w zasadzie powszechne jest przekonanie, że małżeństwo powinno być zawarte na mocy swobodnie wyrażonej woli, ze świadomością konsekwencji tej decyzji. Stąd też małżeństwa zawierane w zbyt młodym wieku, często pod presja ze strony rodziny i otoczenia, sa nieakceptowane ${ }^{1}$. Zawieranie małżeństw przez osoby niedojrzałe ma negatywny wpływ na ich edukację, zdrowie fizyczne i psychiczne oraz pozycję społeczno-ekonomiczna. $\mathrm{Z}$ tego powodu takie praktyki sa niezgodne $\mathrm{z}$ prawami człowieka ${ }^{2}$. Państwa europejskie starają się im więc przeciwdziałać, co przekłada się na konkretne działania legislacyjne podejmowane na gruncie prawa materialnego i prawa kolizyjnego. Nasilenie tych działań jest szczególnie widoczne w ostatniej dekadzie, co spowodowane jest przede wszystkim wzmożoną migracją do Europy z państw należących do innych kręgów kulturowych. Małżeństwa dzieci, będąc zjawiskiem silnie osadzonym w kulturze, stały się jedną z płaszczyzn, na których występują tarcia między większością, która co do zasady decyduje o kształcie regulacji prawnych, a mniejszościami, które z jednej strony pragną zamieszkiwać w państwach europejskich, z drugiej jednak strony chca zachować tradycje, które kultywowane sa w państwach ich pochodzenia ${ }^{3}$.

\section{Kwestie terminologiczne}

W języku polskim brak jest jednolitej terminologii w odniesieniu do tego zjawiska. W języku angielskim używane jest pojęcie child marriages, który można przetłumaczyć jako „małżeństwa dzieci” lub „małżeństwa dziecięce”. Również zakres tego pojęcia nie jest ściśle określony.

${ }^{1}$ S. M e n z: Stateless and Child Marriage as Intersectional Phenomena: Instability, Inequality, and the Role of the International Community. "California Law Review" 2016, vol. 104, nr 2, s. 516.

${ }^{2}$ Zob. E. K a m a r a d: Mał̇eństwa dziecięce $w$ świetle praw człowieka, w: Prawa człowieka wobec wyzwań wspótczesnego świata. Red. E. S z c z e p a n k i e w i c z - R u d z k a, A. C z u b i k, D. D z i w i s z. Kraków 2019, s. 244-245.

${ }^{3}$ M. J ä n t e r ä - J a r e b o r g: The Child in the Intersections between Society, Family, Faith and Culture, w: The Child's Interests in Conflict. The Intersections between Society, Family, Faith and Culture. Red. M. J ä n t e r ä -J a r e b o r g. Cambridge-Antwerp-Portland 2016, s. 22. 
Zazwyczaj „małżeństwa dzieci” definiowane są jako małżeństwa zawierane przez osoby, z których przynajmniej jedna jest poniżej określonego wieku. Najczęściej granicę wieku w tym przypadku wyznacza 18. rok życia, co związane jest $\mathrm{z}$ definicją dziecka, która zawarta jest w aktach prawa międzynarodowego, w tym przede wszystkim w Konwencji o prawach dziecka ${ }^{4}$ z 1989 r. Zgodnie z art. 1 konwencji „dziecko oznacza każdą istotę ludzką w wieku poniżej osiemnastu lat, chyba że zgodnie z prawem odnoszacym się do dziecka uzyska ono wcześniej pełnoletność." Sama Konwencja odwołuje się więc w tym zakresie do prawa krajowego państw, będących jej stronami. Także Konwencja w sprawie likwidacji wszelkich form dyskryminacji kobiet ${ }^{5}$ z 1979 r., która w art. 16 ust. 2 stanowi, że małżeństwo dziecka nie będzie miało skutku prawnego, nie definiuje tego pojęcia. Nakazuje jedynie państwom będącym stronami do podjęcia wszelkich niezbędnych kroków w kierunku określenia dolnej granicy wieku zdolności do zawarcia małżeństwa. Natomiast w rezolucji przyjętej w ramach Rady Europy ${ }^{6}$ małżeństwa dzieci są w pkt. 7 zdefiniowane jako zwiąek dwóch osób, z których co najmniej jedna nie ukończyła 18 roku życia. Tak też rozumiane jest małżeństwo dzieci na gruncie rozwiązań prawnych przyjętych w niektórych państwach europejskich, które mają na celu przeciwdziałanie takim małżeństwom.

\section{Minimalny wiek zawarcia małżeństwa}

Najczęściej państwa określają minimalny wiek wymagany dla zawarcia małżeństwa przepisami prawa materialnego ${ }^{7}$. Często jednak zawarcie małżeństwa jest możliwe pomimo nieosiągnięcia minimalnego wieku, za zgodą opiekunów prawnych albo po wydaniu odpowiedniego

${ }^{4}$ Konwencja o prawach dziecka przyjęta przez Zgromadzenie Ogólne Narodów Zjednoczonych dnia 20 listopada 1989 r., Dz.U. z dnia 23 grudnia 1991 r. Nr 120, poz. 526.

${ }^{5}$ Konwencja w sprawie likwidacji wszelkich form dyskryminacji kobiet przyjęta przez Zgromadzenie Ogólne Narodów Zjednoczonych dnia 18 grudnia 1979 r., Dz.U. 1982 nr 10 poz. 71 .

${ }^{6}$ Rezolucja nr 1468 Zgromadzenia Parlamentarnego Rady Europy dotycząca małżeństw przymusowych i małżeństw dzieci z 5 października $2005 \mathrm{r}$.

${ }^{7}$ D. C o e s t e r - W a l t j e n, M. C o e s t e r: Formation of Marriage, w: International Encyclopedia of Comparative Law. Volume IV. Persons and Family. Red. A. C h 1 o r o s, M. R h e i n s t e i n, M.A. G l e n d o n, Tübingen 2007, chapter 3, s. 15. 
zezwolenia przez sąd lub inny kompetentny organ. Sytuacje, w których jest to możliwe bywaja określone w przepisach prawnych ${ }^{8}$.

Większość państw europejskich jako generalną zasadę stosuje regułę, zgodnie z którą małżeństwo może być zawarte przez osobę, która ukończyła 18. rok życia9 ${ }^{9}$ Wyjątek w tym zakresie stanowi regulacja szkocka, która zezwala osobom majacym domicyl w Szkocji na zawarcie małżeństwa, jeśli ukończyły one 16 lat $^{10}$. Ustawodawstwa europejskie znacznie różnią się jednak pod względem tego, w jakich sytuacjach i od jakiego wieku można zezwolić na zawarcie małżeństwa osobie, która nie ukończyła 18 lat.

Część państw w ogóle nie dopuszcza wyjątków w tym zakresie. Do tych państw należą m.in.: Dania, Holandia, Szwecja i Niemcy. Zmiany w prawie polegające na derogacji przepisów umożliwiajacych zawarcie małżeństwa przez osobę poniżej 18. roku życia zostały w tych państwach przyjęte na przestrzeni ostatnich lat, co wpisuje się w pewien trend, który zostanie bardziej szczegółowo omówiony w dalszej części artykułu.

Pozostałe państwa w drodze wyjątku pozwalają na zawarcie małżeństwa przez osobę, która nie ukończyła 18 lat. Art. 46 hiszpańskiego kodeksu cywilnego ${ }^{11}$ stanowi zasadę, że dorosłość osiaga się wraz z ukończeniem 18 lat, jednak art. 314 pozwala na emancypację przez zawarcie małżeństwa, a art. 317 stanowi, że osoba, która ukończyła 16 lat może zawrzeć małżeństwo za zgodą sądu. Do 2015 r. zawarcie małżeństwa było możliwe za zgodą rodziców od 16. roku życia, a za zgodą sądu — od 14. roku życia. Obecnie, po nowelizacji odpowiednich przepisów, zawarcie małżeństwa przez osobę, która nie ukończyła 16 lat nie jest możliwe, a przez osobę mająca od 16 do 18 lat - tylko za zgodą sądu ${ }^{12}$.

W prawie portugalskim zgodnie $\mathrm{z}$ art. 1601a) ${ }^{13}$ jedna z przeszkód małżeńskich jest nieukończenie 16. roku życia. Zgodnie z art. 1612 zawarcie małżeństwa przez osobę, która ukończyła 16 lat, ale nie ukończyła 18 lat może nastąpić jedynie za zgodą jej opiekunów prawnych oraz za zgodą urzędnika stanu cywilnego, która może być wydana tylko wówczas, gdy

${ }^{8}$ Przykład może stanowić art. $10 \S 1$ polskiego Kodeksu rodzinnego i opiekuńczego, ustawa z dnia 25 lutego 1964 r., Dz.U. 1964 Nr 9 poz. 59.

${ }_{9}^{9}$ Dane z raportu FRA Mapping minimum age requirements concerning the rights of the child in the EU, https://fra.europa.eu [dostęp 30.06.2019].

${ }^{10}$ Art. 1 (1) ustawy prawo małżeńskie (ang. Marriage (Scotland) Act) z 26 maja 1977 r., c. 15.

${ }^{11}$ Kodeks cywilny (hiszp. Código Civil) z 24 lipca 1889 r., BOE-A-1889-4763.

${ }^{12}$ M. L i n a c e r o d e l a F u e n t e: Primera Parte. Derecho de Famila, w: Tratado de derecho de familia. Aspectos sustantivos. Red. M. L i n a c e r o d e l a F u e n t e. Valencia 2016, s. 95.

${ }^{13}$ Kodeks cywilny (pt. Código Civil) z 25 listopada 1966 r., nr 47344/66. 
istnieją istotne powody, aby małżeństwo było zawarte, a małoletni jest odpowiednio dojrzały psychicznie i fizycznie.

$\mathrm{W}$ chorwackiej ustawie o prawie rodzinnym ${ }^{14}$ przewidziano, że zawarcie małżeństwa może nastąić po ukończeniu 18. roku życia, jednak sąd może zezwolić na zawarcie małżeństwa osobie, która ma 16 lat, jeśli stwierdzi, że jest ona mentalnie i fizycznie dojrzała do małżeństwa, oraz że jest to zgodne z interesem tej osoby i nie narusza jej dobra.

Podobna regulacja obowiązuje we Włoszech. Art. 84 kodeksu cywilnego ${ }^{15}$ stanowi, że nieletni, tj. osoby poniżej 18. roku życia, nie mogą zawierać małżeństwa. Jednak sąd, na wniosek zainteresowanej strony, po upewnieniu się, że jest ona dojrzała psychofizycznie oraz po ocenie ważności podanych powodów, po wysłuchaniu prokuratora, rodziców lub opiekunów, może przyznać prawo do zawarcia małżeństwa osobie, która ukończyła lat 16.

W Estonii, zgodnie z $§ 1(2)$ ustawy o prawie rodzinnym ${ }^{16}$, tylko dorosły, tj. osoba mająca ukończone 18 lat, może zawrzeć małżeństwo. Jednak §1(3) przewiduje możliwość przyznania przez sąd osobie, która ukończyła 15 lat zdolności do czynności prawnych wymaganej do zawarcia małżeństwa i do wykonywania praw i obowiązków wynikających ze stosunku małżeństwa.

W prawie litewskim wiek zawarcia małżeństwa uregulowany jest w art. 3.14 kodeksu cywilnego ${ }^{17}$. Co do zasady małżeństwo może być zawarte przez osobę, która ukończyła 18 lat, jednak na wniosek osoby mającej zawrzeć małżeństwo sąd może obniżyć ten wiek, ale maksymalnie o 3 lata, a więc do 15 lat. Art. 3.14 ust. 3 stanowi jednak, że wyjątkowo, w przypadku ciąży, sąd może zezwolić na zawarcie małżeństwa nawet osobie będącej poniżej 15. roku życia ${ }^{18}$. Przed podjęciem takiej decyzji

\footnotetext{
${ }^{14}$ Art. 25 ustawy Prawo rodzinne (hr. Obiteljski zakon) z 18 września 2015 r., NN $103 / 15$.

${ }^{15}$ Kodeks cywilny (wł. Codice Civile) z 16 marca 1942 r., G.U. nr 79.

${ }_{16}$ Ustawa Prawo rodzinne (et. Perekonnaseadus) z 18 listopada 2009 r., RT 2009, 60, 395 .

${ }^{17}$ Kodeks cywilny (lt. Civilinis Kodeksas) z 18 lipca 2000 r., nr 74-2262.

${ }^{18}$ Wyjątek ten wydaje się analogiczny do tego przewidzianego w art. $10 \S 1$ polskiego
} Kodeksu rodzinnego i opiekuńczego (Dz.U. 1964 Nr 9 poz. 59), jednak warto zauważyć, że inaczej niż w prawie polskim, w prawie litewskim możliwość udzielenia zezwolenia na zawarcie małżeństwa przez osobę poniżej określonego wieku dotyczy zarówno kobiety, jak i mężczyzny. Takie rozwiązanie, abstrahując od braku ustalonej granicy wieku, od którego może być udzielone, wydaje się trafniejsze niż to przyjęte w prawie polskim, nie stanowi bowiem rozwiązania dyskryminującego ze względu na płeć nupturientów. $\mathrm{Na}$ gruncie prawa litewskiego bez znaczenia jest czy osoba, której sąd wydaje zgodę na zawarcie małżeństwa jest matką czy ojcem nienarodzonego dziecka. W prawie polskim natomiast możliwość taka istnieje jedynie wówczas, gdy to kobieta nie ukończyła 18 lat, zaś gdy dziecka oczekuje para, w której to ojciec ma poniżej 18 lat, wówczas zezwolenie 
sąd powinien wziąć pod uwagę poziom rozwoju psychicznego i fizycznego nupturienta, jego sytuację finansową i rodzinną oraz inne ważne powody, dla których małżeństwo powinno być zawarte. Sąd jest także zobligowany do wysłuchania opinii rodziców lub opiekunów prawnych nupturienta. W postępowaniu opinię powinna także wydać instytucja państwowa powołana do ochrony praw dziecka.

Można wyróżnić także takie państwa, które przewidują możliwość uzyskania zgody na zawarcie małżeństwa przez osobę, która nie ukończyła 18 lat, jednak prawo nie określa dolnej granicy wieku osoby, która może się o takie zezwolenie starać. Takie rozwiązanie przyjęte jest przykładowo w prawie belgijskim. Zgodnie z art. 145 kodeksu cywilnego ${ }^{19}$, z ważnych powodów sąd rodzinny może zezwolić na zawarcie małżeństwa osobie, która nie skończyła 18 lat. Wniosek w tym zakresie moga złożyć rodzice nupturienta lub jedno z nich, opiekun lub sam nupturient, o ile rodzice lub opiekun nie wyrażaja zgody na zawarcie małżeństwa. Podobne rozwiązania, bez określenia dolnej granicy wieku, od której może zostać udzielona nieletniemu zgoda na zawarcie małżeństwa, obowiązują przykładowo w Luksemburgu, Francji, Grecji i Słowenii.

W USA ${ }^{20}$ małżeństwo jest materią, która tradycyjnie podlega legislacji stanowej, a nie federalnej. Większość stanów przewiduje 18 lat jako minimalny wiek zawarcia małżeństwa. Jednak we wszystkich z nich, jako wyjątek od reguły, możliwe jest zawarcie małżeństwa przez osobę,

na zawarcie małżeństwa nie może zostać udzielone. Takie rozwiązanie ma charakter dyskryminujący ze względu na płeć (K. P i e t r z y k o w s k i: Kodeks rodzinny i opiekuńczy. Komentarz. Red. K. P i e t r z y k o w s k i. Warszawa 2018, s. 187). Pierwotnie rządowy projekt ustawy z 24 lipca 1998 r. przewidywał odmienne rozwiązanie, zgodnie z którym sąd rodzinny mógł udzielić zezwolenia na zawarcie małżeństwa osobie (a więc kobiecie lub mężczyźnie), która ukończyła 16 lat. Zrezygnowano z tego rozwiązania mając na uwadze dobro rodziny, w szczególności względy ekonomiczne. Zezwolenie najczęśs ciej jest bowiem wydawane w sytuacji, gdy kobieta spodziewa się dziecka lub już je urodziła, a, zgodnie z założeniem przyjętym przez ustawodawcę, w takiej sytuacji dorosłemu mężczyźnie łatwiej jest utrzymać rodzinę. (J. G a j d a: Unieważnienie mał̇̇eństwa, w: System prawa prywatnego. Tom 11. Prawo rodzinne i opiekuńcze. Red. T. S m y c z y ń - s k i. Warszawa 2009, s. 148.)

${ }^{19}$ Kodeks cywilny (nl. Burgerlijk Wetboek) z 21 marca 1804 r., nr 1804032150.

${ }^{20}$ Dane statystyczne pokazuja, że małżeństwa dzieci nie są w USA problemem marginalnym, lecz występują stosunkowo często. W latach 1995—2012 w stanie New Jersey 3499 nieletnich zawarło małżeństwa, w tym 178 zostało zawartych przez osoby poniżej 15. roku życia. $91 \%$ z tych małżeństw było zawarte przez osoby o takiej różnicy wieku, że w innych okolicznościach oznaczałoby to postawienie zarzutów gwałtu na nieletnim (ang. statutory rape). W latach 2000-2010 w stanie Nowy Jork 3853 nieletnich zawarło małżeństwa, a w stanie Virginia w latach 2000-2013 - 4500 nieletnich. Dane na postawie raportów przytoczone przez E.M. L a n d a u: Custom or Crime? (Part IV of IV). A National Response to Forced Marriage in the US. "American Journal of Family Law" 2016, vol. 30, nr 3, s. 173. 
która nie ukończyła 18 lat. Nie we wszystkich stanach wymagana jest decyzja sądu w tym zakresie, w niektórych wystarcza wyrażenie zgody przez rodziców lub opiekunów prawnych albo udowodnienie ciąży lub urodzenie dziecka ${ }^{21}$. W niektórych stanach $\mathrm{w}$ takiej sytuacji prawnie możliwe jest zawarcie małżeństwa przez 12 - i 13-latków ${ }^{22}$.

Możliwa jest także sytuacja, w której minimalny wiek wymagany do zawarcia małżeństwa jest ustalony prawnie, natomiast wyjątki od niego określone sa prawem religijnym lub zwyczajowym. Przykładowo w Zimbabwe obowiązuja dwa akty prawne dotyczące zawarcia małżeństwa: prawo o małżeństwie ${ }^{23}$ i prawo o małżeństwie zwyczajowym ${ }^{24}$. Pierwsza regulacja wymaga do zawarcia małżeństwa ukończenia przez mężczyznę 18. roku życia, a przez kobietę 16. roku życia. Dopuszczalne jest jednak zawarcie małżeństwa przez osoby młodsze, jeśli wyrazi na to zgodę minister sprawiedliwości. Z kolei regulacja dotycząca małżeństw zwyczajowych nie określa minimalnego wieku wymaganego dla zawarcia małżeństwa. Tradycyjnie dopuszczalne są małżeństwa zawierane przez osoby, które osiagnęły dojrzałość, w praktyce oznacza to jednak, że małżeństwa są zawierane przez dziewczęta, które maja ukończone 12 lat $^{25}$. Co więcej, powszechna praktyką jest brak rejestracji małżeństw zwyczajowych ${ }^{26}$, przez co organy państwowe nie mają żadnej kontroli nad tym, w jakim wieku są osoby, które wstępują w związek małżeński ${ }^{27}$.

Koran zawiera szczegółowe zasady dotyczące zawierania małżeństw, które w większości przedstawiane sa na podstawie opisów z życia proroka Mahometa ${ }^{28}$. Prawo muzułmańskie nie określa jednak minimalnego wieku wymaganego do zawarcia małżeństwa ${ }^{29}$. Aby małżeństwo było

${ }^{21}$ Ibidem, s. 173.

${ }^{22}$ E.M. L a n d a u: Custom or Crime? (Part II of IV). Legal Remedies for Forced Marriage Victims and Survivors. "American Journal of Family Law" 2016, vol. 30, nr 1, s. $46-47$.

${ }^{23}$ Ang. The Marriage Act z 1 marca 1965 r., Cap. 55:11.

${ }^{24}$ Ang. The Customary Marriage Act z 1 stycznia 1951 r., Cap. 5:07.

${ }^{25} \mathrm{~J} . \mathrm{S} \mathrm{l}$ o t h - N i e l s e n: Child Marriage in Zimbabwe? The Constitutional Court Rules 'No', w: The International Survey of Family Law 2016 Edition. Red. B. A t k i n. Bristol 2016, s. 545.

${ }^{26}$ Ibidem, s. 537.

${ }^{27}$ Powyższa sytuacja ma szansę ulec zmianie po niedawnym orzeczeniu Trybunału Konstytucyjnego, w którym stwierdził on, że małżeństwo zawarte przez osobę poniżej 18. roku życia jest nieważne. Dotyczy to wszystkich małżeństw zawartych po dacie wydania orzeczenia, tj. po 20 stycznia 2016 r., niezależnie od tego, czy zostały zarejestrowane oraz bez względu na to, czy są to małżeństwa cywilne, czy zwyczajowe. Zob. J. S lo t h - N i e l s e n, op. cit., s. 546-553.

${ }^{28}$ M.H. K a m a l i: Shari'ah Law: An Introduction. Oxford 2008, s. 52.

${ }^{29}$ A.A. K h a n, T.M. K h a n: Encyclopaedia of Islamic Law 5. Family Law in Islam. New Delhi 2010, s. 5. 
ważne, obie strony muszą mieć zdolność do jego zawarcia. Zgodnie z teorią klasycznego prawa muzułmańskiego, uzyskanie zdolności do zawarcia małżeństwa jest ściśle związane z dojrzewaniem. W teorii powinno ono być rozumiane jako osiągnięcie dojrzałości umysłowej i psychicznej. Wyznaczenie konkretnego momentu jest jednak w takim przypadku bardzo subiektywne, toteż z czasem większy nacisk został położony na dojrzewanie płciowe, które można określić dokładnie, jako że łączy się $\mathrm{z}$ wystapieniem określonych symptomów o charakterze biologicznym ${ }^{30}$. Moment ten jest więc określany niezależne w stosunku do każdej osoby, a generalne zasady $\mathrm{w}$ tym zakresie maja zastosowanie jedynie wówczas, gdy brak jest oznak dojrzewania płciowego. Poszczególne szkoły prawa islamu różnie jednak definiują wiek, w którym rozpoczyna się dojrzewanie. Przedstawiciele szkoły hanafickiej zakładają, że dojrzewanie rozpoczyna się nie wcześniej niż w wieku 12 lat w przypadku chłopców i 9 lat w przypadku dziewcząt oraz nie później niż w wieku — odpowiednio - 18 i 17 lat. Szkoły szaficka i hanabalicka określaja tę granicę wieku na 15 lat dla obu płci, z kolei szkoła malikicka - na 17 lat. Natomiast przedstawiciele szkoły dżafaryckiej, będącej szkoła prawną szyizmu, uważają, że wiek, w którym rozpoczyna się dojrzewanie to 15 lat dla chłopców i 9 lat dla dziewcząt ${ }^{31}$. Wszystkie szkoły zgadzają się co do tego, że koniecznym elementem zawarcia małżeństwa jest swobodne wyrażenie woli. Bez tego małżeństwo jest nieważne z mocy prawa, od momentu jego zawarcia. Jednak w przypadku osoby, która nie osiągnęła pełnoletności, zgoda na zawarcie małżeństwa powinna być wyrażona przez opiekuna prawnego ${ }^{32}$. Małżeństwo zawarte w ten sposób może być rozwiązane przez małoletnią żonę po osiągnięciu przez nią dojrzałości płciowej. Jeżeli zgodę na zawarcie małżeństwa wyraziła inna osoba niż ojciec lub ojciec ojca rozwiązanie małżeństwa może nastąpić w każdym przypadku. Jeśli natomiast zgodę na zawarcie małżeństwa wyraził ojciec lub ojciec ojca osoby małoletniej, wówczas małżeństwo może być rozwiązane, jeśli zgoda na nie została wyrażona w wyniku oszustwa lub w sposób lekkomyślny ${ }^{33}$. W każdym przypadku wola rozwiązania małżeństwa powinna zostać wyrażona przez osobę małoletnią natychmiast po osiągnięciu dojrzałości, gdyż potem uprawnienie to wygasa. Taki sam skutek

${ }^{30}$ C. G. B a u g h: Minor Marriage in Early Islamic Law. Leiden-Boston 2017, s. 53.

${ }^{31} \mathrm{~A}$. B ü c h l e r, Ch. S c h l a t t e r: Marriage Age in Islamic and Contemporary Muslim Family Laws. A Comparative Survey. "Electronic Journal of Islamic and Middle Eastern Law" 2013, vol. 1, s. 40.

${ }^{32}$ T. F a t i m a: Marriage Contract in Islam. New Delhi 2007, s. 48.

${ }^{33}$ Ibidem, s. 48. 
powoduje skonsumowanie małżeństwa. Powyższe rozwiąanie prawne nosi nazwę „wyboru przy dojrzewaniu” (arab. Khyar-ul-Bulugh) ${ }^{34}$.

$\mathrm{W}$ państwach, w których dominująca religia jest islam, minimalny wiek zawarcia małżeństwa jest także określony przez powszechnie obowiazujace przepisy prawa. Mimo że prawo to jest oparte na Koranie, to dzięki jego nowej interpretacji, bardziej odpowiadającej współczesnej rzeczywistości, możliwe było przeprowadzenie reform $\mathrm{w}$ dziedzinie prawa małżeńskiego ${ }^{35}$. Skutkiem tych zmian w latach 50. i 60 . XX wie$\mathrm{ku} \mathrm{w}$ wielu państwach muzułmańskich na Bliskim Wschodzie, w Azji i w Afryce przyjęto nowe kodeksy w dziedzinie prawa cywilnego, prawa personalnego i prawa rodzinnego. Wówczas w wielu państwach wiek zawarcia małżeństwa został po raz pierwszy określony przepisami prawa lub podwyższony w porównaniu do uprzednio obowiąujących regulacji w tym zakresie ${ }^{36}$. Obecnie minimalny wiek zawarcia małżeństwa wymagany prawem waha się w państwach muzułmańskich od 15 do $21 \mathrm{w}$ stosunku do mężczyzn i od 13 do $18 \mathrm{w}$ stosunku do kobiet ${ }^{37}$. Wyjątek w tym zakresie stanowią takie państwa, jak Jemen i Arabia Saudyjska, których prawodawstwo nie przewiduje regulacji w tym zakresie ${ }^{38}$. Oznacza to, że przy zawieraniu małżeństwa mają zastosowanie jedynie ograniczenia wynikające z prawa religijnego ${ }^{39}$.

Część państw, w których obowiązuje prawo szariatu, przewiduje limit wieku, jaki musi zostać osiągnięty przez nupturientów, aby małżeństwo mogło być zawarte. Prawo pozwala jednak na zwolnienie od spełnienia tego wymogu, niekiedy bez określania dolnej granicy wieku, tak jak ma to miejsce przykładowo w Katarze, Kuwejcie, Bangladeszu, Pakistanie czy Indonezji ${ }^{40}$.

Małżeństwa dzieci występują powszechnie nie tylko w państwach muzułmańskich, lecz także w państwach, w których dominująca religia jest hinduizm. Obowiązek zaaranżowania małżeństwa zanim córka

\footnotetext{
${ }^{34}$ Ibidem, s. $53-55$.

${ }^{35}$ M.H. K a m a 1 i, op. cit., s. 252.

${ }^{36}$ Ibidem, s. 272.

${ }^{37}$ J. J. N a s i r: The Status of Women Under Islamic Law and Under Modern Islamic Legislation. London 1994, s. 7-9.

${ }^{38} \mathrm{M}$. A r t h u r et al:: Child Marriage Laws around the World: Minimum Marriage Age, Legal Exceptions, and Gender Disparities. "Journal of Women, Politics \& Policy" 2018, vol. 39, nr 1, s. 60.

${ }^{39}$ A. B ü c h l e r, Ch. S c h l a t t e r: Marriage Age..., s. 58.

${ }^{40}$ Raport State of the World's Children przygotowany w 2017 r. przez UNICEF. Raport dostępny na oficjalnej stronie internetowej UNICEF: https://www.unicef.org/ [dostęp 30.06.2019].
} 
osiągnie dojrzałość płciową wynika z religii ${ }^{41}$, ale w praktyce związane jest także z innymi czynnikami - z poziomem ubóstwa i pozycją kobiety w społeczeństwie ${ }^{42}$. Państwem, w którym od wielu dekad prawo jest narzędziem wykorzystywanym do walki z małżeństwami dzieci, sa Indie. W 1904 r. przyjęto Early Marriage Prevention Act, na mocy którego małżeństwo zawarte przez dziewczynkę będąca poniżej 9. roku życia było nieważne. W przypadku małżeństwa zawieranego przez dziewczynkę, która nie ukończyła 12 lat lub chłopca, który nie ukończył 16 lat należało uzyskać zgodę lokalnego trybunału ${ }^{43}$. W 1929 r. przyjęto Child Marriage Restraint Act, który dotyczył głównie konsekwencji karnych aranżowania małżeństw dzieci, nie odnosił się jednak do ważności tych małżeństw. Dopiero w 1938 r. wprowadzono poprawkę ${ }^{44}$, na mocy której sąd mógł wydać zakaz zawarcia takiego małżeństwa. Zabiegi legislacyjne hinduskiego prawodawcy często sa podawane jako przykład działań, które odniosły odwrotny skutek od zamierzonego. Brak skutecznego egzekwowania przyjętego prawa oznaczało w praktyce przyzwolenie na to, aby małżeństwa dzieci były nadal zawierane ${ }^{45}$. Sytuacji tej dodatkowo sprzyjał fakt, że w Indiach, także obecnie, nie obowiązuje wymóg rejestracji małżeństw ${ }^{46}$.

Kolejne zmiany w prawie prowadziły do podwyższania wieku wymaganego do zawarcia małżeństwa oraz zaostrzały kary za organizowanie małżeństw dzieci ${ }^{47}$. Problemem było jednak to, że małżeństwo zawarte przez osoby będace poniżej wymaganego prawem wieku nie jest ani nieważne, ani unieważnialne, co potwierdzają rozstrzygnięcia sądów ${ }^{48}$. Jedyną możliwością zakończenia małżeństwa jest uzyskanie rozwodu ${ }^{49}$, jednak to rozwiązanie nie jest najczęściej akceptowane ze względu na normy religijne i obyczajowe.

${ }^{41}$ W. F. M e n s k i: Hindu Law Beyond Tradition and Modernity. New Delhi 2003, s. 326, s. 333 .

${ }^{42} \mathrm{~S} . \mathrm{M}$ a h a t o: Causes and Consequences of Child Marriage: A Perspective. "International Journal of Scientific and Engineering Research" 2016, vol. 7, no. 7, s. 698—699.

${ }^{43}$ W.F. M e n s k i: Hindu Law..., s. 339.

${ }^{44}$ Ibidem, s. $341-343$.

${ }^{45}$ Ibidem, s. 344.

${ }^{46}$ Ibidem, s. 326.

${ }^{47}$ W 1949 r. przyjęto The Child Marriage Restraint (Amendment) Act, który został ponownie znowelizowany w $1978 \mathrm{r}$.

${ }^{48}$ W. F. Menski: Hindu Law..., s. 325.

${ }^{49}$ B.M. G h a n d i: Hindu Law. Lucknow 2008, s. 269-270. 


\section{Kolizyjnoprawne aspekty małżeństw dzieci}

W części państw, w tym w większości państw europejskich ${ }^{50}$, prawo właściwe dla materialnoprawnych przesłanek zawarcia małżeństwa, w tym dla minimalnego wieku wymaganego dla zawarcia małżeństwa, wskazane jest za pomoca łącznika personalnego nupturienta ${ }^{51}$. Występujące między porządkami prawnymi poszczególnych państw różnice dotyczące określenia minimalnego wieku wymaganego dla zawarcia małżeństwa powoduja trudności na gruncie kolizyjnoprawnym. Mogą mieć one dwojaki charakter.

Po pierwsze, problem może powstać w odniesieniu do zawarcia małżeństwa, gdy prawo personalne nupturienta pozwala mu zawrzeć małżeństwo, które nie może być zawarte zgodnie z lege loci celebrationis matrimonii. W odniesieniu do minimalnego wieku zawarcia małżeństwa oznacza to, że prawo personalne nupturienta określa minimalny wiek zawarcia małżeństwa niżej, niż prawo obowiązujące w państwie, w którym małżeństwo miałoby być zawarte ${ }^{52}$. W takiej sytuacji powstanie pytanie czy zawarcie małżeństwa mogłoby zostać zablokowane przez powołanie się na klauzulę porządku publicznego. Wszystko oczywiście będzie zależało od konkretnego przypadku, w tym od katalogu podstawowych zasad, które tworzą porządek prawny państwa forum. Jeśli należy do nich zasada społecznej wartości małżeństwa, to zastosowanie klauzuli porządku publicznego będzie generalnie możliwe. Małżeństwo jako instytucja społeczna jest regulowane prawnie we wszystkich porządkach prawnych świata, a określenie przez prawo przesłanek, które muszą być

${ }^{50}$ Wyjątkiem sa państwa skandynawskie - Dania i Szwecja, oraz Łotwa, których prawo kolizyjne przewiduje poddanie zawarcia małżeństwa (tj. zarówno przesłanek materialnych, jak i formalnych) prawu państwa, w którym małżeństwo jest zawierane, ale $\mathrm{w}$ prawie łotewskim tylko w odniesieniu do małżeństw zawieranych na terytorium Łotwy, natomiast w przypadku małżeństw zawieranych za granica zastosowane zostało klasyczne rozwiązanie, tj. zastosowanie prawa ojczystego dla oceny materialnych przesłanek zawarcia małżeństwa oraz prawa miejsca zawarcia małżeństwa dla oceny formy.

${ }^{51}$ L. P å l s s o n: Marriage and Divorce, w: International Encyclopedia of Comaprative Law. Volume III. Private International Law. Part 2. Red. K. L i p s t e i n. Tübingen 2011, chapter 16 , s. 58-59.

52 Teoretycznie mogłaby wystąić sytuacja odwrotna, w której prawo obowiąujące w miejscu zawarcia małżeństwa przewiduje maksymalna granicę wieku, po osiągnięciu którego zawarcie małżeństwa nie jest możliwe. Współcześnie jednak takie regulacje nie występują w żadnym prawodawstwie, a więc po osiągnięciu określonego wieku zawarcie małżeństwa jest możliwe, co do zasady, aż do śmierci. Zob. D. C o e s t e r - W a l t j e n, M. C o e s t e r, op. cit., s. 3.-26. 
spełnione przez nupturientów, oraz przeszkód, które nie mogą wystąić, aby małżeństwo zostało skutecznie zawarte, służy właśnie jej realizacji.

Sama różnica w określeniu minimalnego wieku uprawniającego do zawarcia małżeństwa $\mathrm{w}$ porządku państwa pochodzenia nupturienta i państwa, w którym małżeństwo ma być zawarte nie wystarcza jednak, aby zastosować klauzulę porządku publicznego. Wiek zawarcia małżenstwa określony prawem wewnętrznym danego państwa powinien być dostosowany do średniego wieku, w którym osiągana jest dojrzałość fizyczna i psychiczna, a to z kolei uzależnione jest od wielu czynników, nie tylko natury biologicznej, ale i społecznej ${ }^{53}$. Co do zasady zastosowanie powinno więc znaleźć prawo personalne nupturienta, które może przewidywać inną granicę wieku niż prawo państwa, w którym małżeństwo jest zawierane. Powołanie się na klauzulę porządku publicznego nie powinno także nastąić w sytuacji, gdy lex loci celebrationis matrimonii przewiduje, na zasadzie wyjątku, możliwość zawarcia małżeństwa przez osobę, która nie ukończyła określonego wieku. Jeśli bowiem w swoim porządku prawnym zezwala na zawarcie małżeństwa przez osoby poniżej tego wieku, w wyjątkowych okolicznościach, za zgodą sądu lub za zgodą opiekunów, to organy tego państwa nie moga powoływać się na klauzulę porządku publicznego celem zablokowania możliwości zawarcia małżeństwa przez osobę w tym wieku pochodząca z innego państwa.

Jeśli jednak zastosowanie prawa obcego pozwoliłoby na zawarcie małżeństwa przez osobę, która zgodnie z lege loci celebrationis matrimonii nie osiągnęła minimalnego wieku wymaganego do nawiązania relacji intymnych, wówczas klauzula porządku publicznego powinna znaleźć zastosowanie. Zawarcie małżeństwa powoduje bowiem powstanie obowiąków określonych przez prawo, w tym obowiąek wspólnego pożycia, który obejmuje utrzymywanie relacji intymnych. Jeśli jednak utrzymywanie takich relacji przez daną osobę nie jest dopuszczalne z prawnego punktu widzenia ${ }^{54}$, to małżeństwo nie jest zdolne do spełniania swojej roli, a więc jego zawarcie jest sprzeczne z zasadą społecznej wartości małżeństwa. Dyskusyjne jest, czy w takim przypadku możliwe byłoby powołanie się na koncepcję powściągliwego stosowania klauzuli porządku publicznego (franc. l'effet attenué), gdy małżeństwo jest zawierane

${ }^{53} \mathrm{E} . \mathrm{W}$ i ś n i o w s k a: Znaczenie wieku przy zawarciu matżenstwa wedtug kodeksu rodzinnego i opiekuńczego. Wrocław 1986, s. 42-43.

${ }^{54}$ A często nawet jest karalne, tak jak ma to miejsce na gruncie polskiego prawa karnego w odniesieniu do osoby, która nie ukończyła 15. roku życia, zgodnie z art. 200 Kodeksu karnego (ustawa z dnia 19 kwietnia 1969 r., Dz. U. z 1969 r. Nr 13, poz. 94.) 
w jednym państwie, ale jego skutki, w tym nawiązanie relacji intymnych, miałyby wystąicić w innym państwie ${ }^{55}$.

Jeśli prawo państwa, w którym małżeństwo miałoby zostać zawarte, nie przewiduje ograniczeń dotyczacych minimalnego wieku nawiązywania relacji intymnych, wówczas zastosowanie klauzuli porządku publicznego celem uniemożliwienia zawarcia małżeństwa osobie, której prawo personalne na to pozwala, mogłoby nastąpić przez wzgląd na zasadę swobody zawarcia małżeństwa. Zasada ta oznacza, że każda osoba może samodzielnie podjąć decyzję dotycząca zawarcia małżeństwa, w tym wyboru osoby współmałżonka ${ }^{56}$. Korzystanie z tej swobody zakłada jednak, że dana osoba jest w pełni świadoma konsekwencji swojej decyzji, a więc tego, z czym wiąże się zawarcie małżeństwa - jakie prawa i obowiązki wynikają $z$ tego stosunku prawnego. Jeśli więc prawo właściwe dla oceny materialnoprawnych przesłanek zawarcia małżeństwa pozwala na zawieranie małżeństwa przez osoby, których zbyt młody wiek uzasadnia założenie, że nie mają takiego rozeznania, wówczas powinno nastąić powołanie się na klauzule porządku publicznego celem zablokowania możliwości zawarcia takiego małżeństwa. Nie wydaje się, aby ustalanie konkretnej granicy wieku było w tym przypadku konieczne. Jako, że powołanie się na klauzulę porządku publicznego może nastąpić po dokonaniu oceny, jakie skutki będzie miało zastosowanie prawa obcego ${ }^{57}$, to w ramach tej analizy można zbadać poziom dojrzałości danej osoby i zdecydować czy zawarcie przez nią małżeństwa będzie godziło w zasadę swobody zawarcia małżeństwa, czy też nie.

Po drugie, różnice między porządkami prawnymi dotyczące określenia minimalnego wieku wymaganego dla zawarcia małżeństwa moga być przyczyna problemu w przypadku uznania małżeństwa zawartego za granica. Jeśli ze względu na zbyt niski wiek nupturientów małżeństwo nie mogłoby zostać zawarte zgodnie z prawem danego państwa, władze tego państwa moga mieć wattpliwości, czy takie małżeństwo powinno zostać uznane za ważne i skuteczne.

${ }^{55}$ M. J ä n t e r ä - J a r e b o r g: Non-Recognition of Child Marriages: Sacrificing the Global for the Local in the Aftermath of the 2015 'Refugee Crisis', w: International and National Perspectives on Child and Family Law. Essays in Honour of Nigel Lowe. Red. G. D o u g l a s, M. M u r c h, V. S t e p h e n s. Cambridge-Antwerp-Portland 2018, s. 275.

${ }^{56}$ D. C o e s t e r - W a l t j e n, M. C o e s t e r: Formation of Marriage..., s. 3.-12-14.

${ }^{57}$ K. P r z y b y $ł$ o w s k i: Prawo prywatne międzynarodowe. Lwów 1935, s. 172 173; M. S o ś n i a k: Klauzula porzqdku publicznego $w$ prawie międzynarodowym prywatnym. Warszawa 1961, s. 172. 
W przypadku uznania małżeństwa zawartego za granica zazwyczaj przyjmuje się podejście in favorem matrimonii ${ }^{58}$, tzn. uznanie ważności i skuteczności małżeństwa, jeśli zostało ono zawarte zgodnie z prawem miejsca jego zawarcia ${ }^{59}$. Co do zasady dotyczy to także małżeństw, które nie mogłyby zostać ważnie zawarte w państwie forum, chyba że w grę wchodzi sytuacja, w której może zostać zastosowana klauzula porządku publicznego lub małżeństwo zostało zawarte celem obejścia prawa. Podejście służy ograniczeniu liczby małżeństw tzw. kulejących (ang. limping marriage, fr. mariage boiteux, niem. Hinkende Ehe), tj. ważnych i skutecznych w jednym państwie, ale nieuznanych i niewywołujących skutków prawnych w innym państwie. Taka sytuacja jest bardzo niekorzystna, gdyż z ważnie zawartym małżeństwem związane jest powstanie wielu praw i obowiązków ${ }^{60}$. Jeśli zatem małżeństwo zawarte $\mathrm{w}$ jednym państwie nie jest uznane $\mathrm{w}$ innym, to powoduje to powstanie dualizmu prawnego, który negatywnie wpływa na pewność prawa, zarówno po stronie samych małżonków, jak i osób trzecich i organów państwowych.

Zasadę tę wyraża również Konwencja haska o zawieraniu i uznawaniu ważności małżeństw ${ }^{61}$ z 14 marca 1978 r. Konwencja została podpisana jedynie przez 6 państw, z których tylko 3 dokonały jej ratyfikacji, tj. Australia, Luksemburg i Holandia. Konwencja weszła w życie w 1991 r., wraz z trzecia ratyfikacja. Art. 9 Konwencji stanowi, że małżeństwo ważnie zawarte według prawa obowiąujacego w miejscu zawarcia, będzie uważane za takie we wszystkich umawiających się państwach. Zgodnie $\mathrm{z}$ art. 12 , powyższa zasada ma zastosowanie także wówczas, gdy uznanie małżeństwa jest kwestią wstępną, o ile jednak, według norm kolizyjnych państwa forum, prawem właściwym dla oceny tej kwestii jest prawo państwa-strony ${ }^{62}$. Odmowa uznania małżeństwa może nastąić

${ }^{58}$ Zasada ta, obecna nie tylko w kolizyjnym, ale także w materialnym i procesowym prawie rodzinnym, wynika z zasad współżycia społecznego oraz z konstytucyjnych zasad prawa rodzinnego. Zob. K. P i e t $\mathrm{r}$ z y k o w s k i: Wprowadzenie, w: Kodeks rodzinny $i$ opiekuńczy. Komentarz. Red. K. P i e t r z y k o w s k i. Warszawa 2018, s. 26.

${ }^{59}$ D. C o e s t e r - W a l t j e n: Marriage, w: Encyclopedia of Private International Law. Red. J. B a s e d o w, G. R ü h l, F. F e r r a r i, P. d e M i g u e l A s e n s i o. Cheltenham 2017, s. 1227.

${ }^{60}$ A.L. E s t i n: Marriage and Divorce Conflicts in International Perspective. "Duke Journal of Comparative \& International Law" 2017, vol. 27, s. 491—492.

${ }^{61}$ Tekst Konwencji jest dostępny m.in. w języku angielskim, francuskim, hiszpańskim i niemieckim na oficjalnej stronie internetowej HKPPM: http://www.hcch.net/, pod numerem 26.

${ }^{62}$ To właśnie w brzmieniu art. 12 należy upatrywać przyczyny niewielkiej liczby ratyfikacji. Ustalenie ważności małżeństwa zawartego za granicą zazwyczaj nie występuje bowiem jako samodzielny problem, lecz jako kwestia wstępna w innej sprawie, np. alimentacyjnej, spadkowej lub rozwodowej. Konwencja nakazuje jednak uznanie ważno- 
tylko zgodnie z art. 11 lub z art. 14 Konwencji. Art. 11 pozwala na odmowę uznania małżeństwa z powodu zawarcia małżeństwa wbrew zakazowi bigamii, zakazowi pokrewieństwa, zakazowi zawierania małżeństw przez osoby, które nie osiągnęły określonego wieku, nie wyraziły swobodnej zgody na zawarcie małżeństwa lub nie mają wymaganej zdolności umysłowej do rozpoznawania znaczenia swoich czynów. Z kolei art. 14 pozwala na odmowę przez państwo uznania małżeństwa, jeśli jego uznanie byłoby wyraźnie sprzeczne z porządkiem publicznym tego państwa. Nieuznanie małżeństwa $\mathrm{z}$ powyższych powodów nie jest jednak nigdy wymagane, a art. 13 stanowi, że państwo może zastosować bardziej korzystne zasady dotyczące uznawania małżeństwa zawartych zgodnie z prawem pozostałych państw-stron. Konwencja nie reguluje także, jaki jest skutek uznania ważności małżeństwa. To, czy w odpowiednim postępowaniu zostanie stwierdzona nieważność małżeństwa, czy też zostanie ono uznane z mocy prawa za nieważne lub nieistniejące, czy też organy państwa nie przyznają mu żadnych skutków i nie podejmą żadnych konkretnych działań zależy od prawa wewnętrznego danego państwa ${ }^{63}$.

\section{Rozwiązania prawne dotyczące małżeństw dzieci przyjęte przez państwa europejskie}

W odniesieniu do problemu małżeństw dzieci państwa europejskie w ostatnich latach przyjęły rozwiązania prawne, które wyraźnie wyznaczają określony trend. Po pierwsze, zmierzają one do podniesienia minimalnego wieku wymaganego w prawie krajowym dla zawarcia małżeństwa oraz zniesienia wyjątków w tym zakresie, tj. usunięcia możliwości uzyskania zgody na zawarcie małżeństwa pomimo nieukończenia wymaganego wieku. Rozwiązania tego typu przyjęto m.in. w Szwecji, Holan-

ści małżeństwa w takiej sytuacji jedynie wówczas, gdy prawem właściwym dla kwestii wstępnej jest prawo państwa-strony. Niewielka liczba stron ogranicza więc zakres zastosowania Konwencji nie tylko podmiotowo, ale także przedmiotowo, co z kolei wpływa zniechęcająco na państwa, które potencjalnie mogłyby ratyfikować Konwencję. Zob. W.L.M. R e e s e: The Hague Convention on Celebration and Recognition of the Validity of Marriages. "Virginia Journal of International Law" 1979, vol. 20, s. 35-36.

${ }^{63} \AA$. M a 1 m s t r ö m: Convention on Celebration and Recognition of the Validity of Marriages. Explanatory Report. La Haye 1978, s. 305. 
dii, Danii, Norwegii, Niemczech ${ }^{64}$, a także w Hiszpanii ${ }^{65}$ Irlandii $^{66}$ i Finlandii ${ }^{67}$. Na gruncie kolizyjnoprawnym zmiany te maja istotny wpływ na stosowanie klauzuli porządku publicznego. Jeśli bowiem $\mathrm{w}$ prawie materialnym bezwzględnie obowiązuje wymóg ukończenia 18. roku życia przez nupturientów, to wówczas możliwe jest powołanie się na to, że osiagnięcie tego wieku jest zasada o fundamentalnym charakterze dla krajowego prawa rodzinnego, a tym samym jej naruszenie godzin w porządek publiczny danego państwa.

Po drugie, działania legislacyjne podejmowane przez niektóre państwa europejskie widocznie zmierzaja do ograniczenia możliwości funkcjonowania $\mathrm{w}$ ich przestrzeni prawnej małżeństw zawartych za granica przez osoby, które nie osiągnęły wymaganego wieku. Z punku widzenia prawa prywatnego międzynarodowego regulacje prawne przyjmowane $\mathrm{w}$ tym celu prowadzą więc do nieuznawania skutków prawnych małżeństw zawartych zgodnie z legis loci celebrationis matrimonii. Rozwiazania przyjęte przez poszczególne państwa $\mathrm{w}$ tym zakresie różnią się jednak między sobą, stąd też konieczne jest ich krótkie omówienie.

W Holandii problem małżeństw dziecięcych zaczął być widoczny w związku ze zwiększoną migracja. W latach 2014-2016 odnotowano blisko 300 przypadków małżeństw zawartych przez niepełnoletnich imigrantów za granica, głównie w Syrii ${ }^{68}$. W celu zwalczania małżeństw dzieci oraz małżeństw przymusowych w 2015 r. został przyjęty specjalny akt prawny ${ }^{69}$. Na jego mocy podwyższono wiek wymagany do zawarcia małżeństwa do 18 lat. W przypadku małżeństw zawartych za granica przez osoby, które nie ukończyły 18. roku życia, małżeństwa takie nie sa uznawane w Holandii i nie wywołują żadnych skutków prawnych, chyba że każdy z małżonków osiagnął wymagany prawem holenderskim wiek. Tym samym dopiero po ukończeniu przez oboje małżonków 18. roku ży-

\footnotetext{
${ }^{64}$ Rozwiązania przyjęte przez te państwa zostaną omówione szczegółowo w dalszej części.

${ }^{65}$ Art. 317 Kodeksu cywilnego (hiszp. Código Civil) z 24 lipca 1889 r., BOE-A-1889-4763, zmieniony ustawą o dobrowolnej jurysdykcji (hiszp. Ley de la Jurisdicción Voluntaria) z 2 lipca 2015 r., BOE-A-2015-7391.

${ }^{66}$ Art. 31 ustawy o rodzinie (ang. Family Law Act) z 2 października 1995 r., nr 26, znowelizowany ustawą z 1 stycznia 2019 r.

${ }^{67}$ Sekcja 4 ustawy Prawo małżeńskie (fi. Avioliittolain) z 13 czerwca 1929 r., nr 234/1929, znowelizowana ustawą z 15 marca 2019 r., nr 351/2019.

${ }^{68} \mathrm{~A}$. W i j f f e $1 \mathrm{~m}$ a $\mathrm{n}$ : Child marriage and family reunification: an analysis under the European Convention on Human Rights of the Dutch Forced Marriage Prevention Act. "Netherlands Quarterly of Human Rights" 2017, vol. 35, nr 2, s. 104-105.

${ }^{69}$ Ustawa o małżeństwach przymusowych (nl. Wet tegengaan huwelijksdwang) z 6 października 2015 r., BWBR0037085.
} 
cia mogą oni wobec holenderskich władz skutecznie powoływać się na fakt bycia małżeństwem ${ }^{70}$.

W 2017 r. w Danii przyjęta została nowelizacja ${ }^{71}$, na mocy której zniesiono możliwość zwolnienia z wymogu dotyczącego wieku przy zawieraniu małżeństwa. Obecnie więc każdy z nupturientów musi mieć bezwzględnie ukończone 18 lat, aby małżeństwo zawarte w Danii było ważne. W kwestii ważności małżeństw zawartych za granica znowelizowane prawo duńskie przewiduje, że małżeństwo zostanie uznane za ważne, jeśli jest ważne w świetle prawa obowiązującego w miejscu jego zawarcia. Wyjątki od tej zasady przewidziane sa w sekcji 22b.2. W pkt. 3 wymieniona jest sytuacja, w której jeden lub oboje z nupturientów nie ukończyli 18. roku życia w chwili zawarcia małżeństwa ${ }^{72}$. Nieuznanie małżeństwa skutkuje potraktowaniem go jako małżeństwa nieistniejącego. Małżeństwo nie wywołuje więc żadnych skutków prawnych. W szczególności ukończenie 18 lat przez małżonków nie zmienia sytuacji prawnej małżeństwa.

Pomimo tego możliwe jest uznanie małżeństwa, jeśli istnieją ku temu bardzo ważne powody oraz strony postawione byłyby wobec nieuzasadnionych trudności, jeśli małżeństwo nie zostałoby rozpoznane. Co istotne, na podstawie pkt. 4, możliwość nieuznania małżeństwa ze względu na nieukończenie 18. roku życia jest wyłączona, w przypadku małżeństw zawartych przez obywateli państw należących do UE oraz do EOG.

W Norwegii 15 czerwca 2018 r. przyjęto nowelizację $e^{73}$ Ustawy w sprawie małżeństwa ${ }^{74}$. Od momentu jej wejścia w życie, tj. od 1 lipca 2018 r., aby zawrzeć małżeństwo należy mieć bezwzględnie ukończone 18 lat. Przed tą zmianą minimalny wiek zawarcia małżeństwa w Norwegii również wynosił 18 lat, ale w przypadku osoby między 16. a 18. rokiem życia możliwe było zawarcie przez nią małżeństwa po uzyskaniu zgody opiekunów prawnych oraz zgody, która wydawał gubernator okręgu (nor. Fylkesmannen). Obecnie nie ma już takiej możliwości. Jeśli małżeństwo zostanie zawarte w Norwegii przez osobę, która nie ukończyła 18 lat, to

${ }^{70}$ A. Wi j f f e l m a n, Child marriage..., s. 105.

${ }^{71}$ Ustawa o zawarciu i rozwiązaniu małżeństwa (dk. Lov om oegteskabs indgåelse og opløsning) z 27 marca 1990 r., nr 2016, znowelizowany ustawą z 24 stycznia 2017 r., nr 81.

${ }^{72}$ Inne powody nieuznania małżeństwa to: brak obecności obojga nupturientów (tym samym w prawie duńskim wykluczone jest zawarcie małżeństwa przez pełnomocnika), zawarcie małżeństwa dla pozoru (np. w celu uzyskania prawa pobytu w Danii lub UE) oraz niezgodność z duńskim porządkiem publicznym.

${ }^{73}$ Prawo zmieniające ustawę o małżeństwie (bezwzględny wymóg 18 lat dla zawarcia małżeństwa w Norwegii) (nor. Lov om endringer i ekteskapsloven (absolutt 18-årsgrense for å inngå ekteskap $i$ Norge)), LOV-2018-06-15-31.

${ }^{74}$ Ustawa o małżeństwie (nor. Lov om ekteskap) z 4 lipca 1991 r., LOV-1991-07-04-47. 
każdy z małżonków może domagać się rozwiązania takiego małżeństwa z tego powodu. Jeśli żaden z nich o to nie wniesie, wówczas powinien o to wnioskować gubernator okręgu ${ }^{75}$. Co więcej, jeszcze przed wprowadzeniem powyższej zmiany, 18 stycznia 2007 r., przyjęto regulację $e^{76}$, zgodnie z którą do Ustawy o małżeństwie dodany został §18a dotyczący uznawania małżeństw zawartych za granica. Zgodnie z tym przepisem, od 1 lipca 2007 r. małżeństwo ważnie zawarte zgodnie z prawem obowiąujacym w miejscu jego zawarcia jest uznawane w Norwegii. Przepis ten ma za zadanie przeciwdziałać powstawaniu „małżeństw kulejących”"77. Jednakże nie będzie ono uznane, jeśli byłoby to w sposób oczywisty sprzeczne z norweskim porządkiem publicznym. Ponadto, małżeństwo zawarte za granica nie będzie także uznane w Norwegii, jeśli przynajmniej jeden z nupturientów miał w chwili zawarcia małżeństwa norweskie obywatelstwo lub miejsce stałego zamieszkania w Norwegii, a małżeństwo zostało zawarte przez osobę, która nie ukończyła 18. roku życia ${ }^{78}$. Małżeństwo takie może jednak zostać uznane w Norwegii, o ile będą za tym przemawiały poważne powody, a z żądaniem takim wystąpia oboje małżonkowie. Decyzja w tym zakresie należy do gubernatora okręgu (nor. Fylkesmannen). Jest to jednak wyjątek, który powinien być traktowany bardzo wasko i zupełnie wyjątkowo uznanie takiego małżeństwa będzie mogło prowadzić do skorzystania z prawa do łączenia rodzin ${ }^{79}$.

17 lipca 2017 r. w Niemczech przyjęta została ustawa o zwalczaniu małżeństw dzieci (niem. Gesetzes zur Bekämpfung von Kinderehen) ${ }^{80}$, która wprowadziła zmiany w przepisach kolizyjnych odnoszacych się do zawarcia małżeństwa. Geneza ustawy, podobnie jak w pozostałych państwa europejskich, związana była ściśle z kryzysem imigracyjnym. Szczególnie szeroko komentowana była sprawa, która trafiła przed nie-

${ }^{75}$ Informacja Conditions for marriage z oficjalnej strony rządu Norwegii, https:// www.regjeringen.no/, opublikowana 7 stycznia 2019 r. [dostęp 30.06.2019].

${ }^{76}$ Prawo zmieniające Ustawę o małżeństwie i Kodeks postępowania karnego (środki mające na celu przeciwdziałanie małżeństwom z przymusu itp.) (nor. Lov om endringer $i$ ekteskapsloven og straffeprosessloven $\mathrm{mv}$. (tiltak for å forhindre tvangsekteskap mv.)), LOV-2007-01-18-1.

${ }^{77} \mathrm{~K}$. J a n s e s n F r e d r i k s e n: The recognition of transnational Muslim marriages and divorces by Norwegian courts and other competent authorities: dynamics between legislation and legal practice, w: Muslim Family Law in Western Courts. Red. E. G i u n c h i. New York 2014, s. 92-93.

${ }^{78}$ Przepisy zostały sformułowane w ten sposób, że nieukończenie 18. roku życia może dotyczyć zarówno osoby mającej powiązanie z Norwegia, jak i drugiej osoby zawierającej małżeństwo.

${ }^{79}$ Informacja Norway bans child marriages z oficjalnej strony rządu Norwegii, https://www.regjeringen.no/, opublikowana 25 lipca 2018 r. [dostęp 30.06.2019].

${ }^{80}$ Ustawa o zwalczaniu małżeństw dzieci (niem. Gesetzes zur Bekämpfung von Kinderehen) z 17 lipca 2017 r., BGBl. I S. 2429. 
miecki sąd w Bambergu w sierpniu 2015 r. Dotyczyła ona umieszczenia w ośrodku dla uchodźców będących dziećmi bez opieki 14-letniej obywatelki Syrii, która na krótko przed udaniem się do Europy poślubiła swojego 21-letniego kuzyna. Umieszczenie dziewczynki w ośrodku byłoby możliwe jedynie wówczas, gdyby sąd uznał, że nie jest ona zamężna ${ }^{81}$. Jednak w maju 2016 r. sąd uznał, że małżeństwo zostało zawarte zgodnie z prawem właściwym, a więc jest ważne i wywołuje skutki prawne w Niemczech ${ }^{82}$. Wyrok ten był szeroko komentowany w Niemczech i niedługo po tym jak zapadł, przedstawiony został projekt ustawy odnoszacy się do małżeństw dzieci.

Nowelizacja przepisów polegała m.in. na tym, że usunięto możliwość zawarcia małżeństwa przez osoby poniżej 18. roku życia. Uprzednio niemieckie prawo pozwalało na zawarcie małżeństwa osobie, która ukończyła 16 lat, ale nie ukończyła 18 lat, o ile zgodę na to wyraził sad, a drugi nupturient miał skończone 18 lat $^{83}$. Obecnie 18 lat stało się bezwzględnym wiekiem zawarcia małżeństwa i prawo niemieckie nie przewiduje żadnych wyjątków w tym zakresie.

Przed zmianą przepisów skuteczność małżeństw zawartych przez osoby, które nie ukończyły odpowiedniego wieku była w Niemczech oceniana indywidualnie. Pod uwagę były brane okoliczności konkretnej sprawy, m.in. sytuacja małżonków oraz długość trwania ich związku ${ }^{84}$. Przyjęta ustawa zmieniła m.in. treść art. 13 ustawy zawierającej przepisy kolizyjne ${ }^{85}$. Po zmianie zawarcie małżeństwa przez osobę, która nie ukończyła 16. roku życia nie wywołuje z mocy prawa żadnych skutków prawnych, tak jakby nie było nigdy zawarte (niem. Nicht-Ehe) ${ }^{86}$. Z kolei małżeństwo zawarte przez osobę, która w chwili jego zawarcia miała więcej niż 16 lat, ale mniej niż 18, podlega unieważnieniu. Unieważnienie następuje decyzją sądu, jednak powinno następować automatycznie,

${ }^{81}$ P. M a n k o w s k i: Anmerkung zur Entscheidung des OLG Bamberg, Beschluss vom 12.05.2016, 2 UF 58/16 - Zur Anerkennung einer nach syrischem Recht geschlossenen Kinderehe, Zeitschrift für das gesamte Familienrecht 2016, s. 1274-1276.

${ }^{82}$ Postanowienie Sąu Apelacyjnego (niem. Oberlandesgericht) w Bambergu z 12 maja 2016 r., 2 UF 58/16.

${ }^{83}$ M. C o e s t e r: Kinderehen in Deutschland. Stellungnahme der Kinderrechtekommission des Deutschen Familiengerichtstags e. V. [DFGT] v. 29.11.2016. „Zeitschrift für das gesamte Familienrecht" 2017, s. 77.

${ }^{84}$ Ch. v o n B a r: Internationales Privatrechts. München 1991, s. 101-104; M. Z a c h a r i a s i e w i c z: Klauzula porzadku publicznego jako instrument ochrony materialnoprawnych interesów i wartości fori. Warszawa 2018, s. 43.

${ }^{85}$ Ustawa wprowadzająca kodeks cywilny (niem. Einführungsgesetz Bürgerliches Gesetzbuch) z 21 września 1994 r., BGBl. I S. 2494, 1997 I S. 1061.

${ }^{86}$ D. C o e s t e r - W a l t j e n: Kinderehen - Neue Sonderanknüpfungen im EGBGB. „Praxis des Internationalen Privat- und Verfahrensrechts“ 2017, s. 431. 
chyba że mają miejsce specjalne okoliczności ${ }^{87}$. Skutek unieważnienia następuje ex nunc, a więc brane pod uwage sa pewne skutki prawne, które powstały po zawarciu małżeństwa, a przed jego unieważnieniem, np. w odniesieniu do pochodzenia dzieci, prawa do alimentów lub prawa do wyrównania dorobków ${ }^{88}$. Przepisy przewidują, że nieskuteczność lub nieważność małżeństwa małoletniego nie jest brana pod uwagę w przypadku udzielania azylu i tym samym nie prowadzi do pogorszenia jego statusu pobytu. Nie maja jednak wpływu na stosowanie unijnych przepisów o łączeniu rodzin.

Przyjęte przepisy mają zastosowanie zarówno do małżeństw zawieranych na terytorium Niemiec, jak i do małżeństw zawartych za granica. W tym drugim przypadku nie ma znaczenia czy małżeństwo zostało zawarte zgodnie $\mathrm{z}$ prawem właściwym oraz czy w momencie zawarcia małżeństwa istniał jakikolwiek związek z Niemcami, a także kiedy doszło do jego zawarcia małżeństwa i w jakim wieku obecnie są małżonkowie. Małżonkowie mogli więc być $\mathrm{w}$ dobrej wierze, działać zgodnie $\mathrm{z}$ prawem właściwym, a mimo to ich małżeństwo może zostać uznane za bezskuteczne albo unieważnione.

$\mathrm{Z}$ tych powodów niemiecka ustawa trafiła przed Federalny Trybunał Sprawiedliwości (niem. Bundesgerichtshof), który pod koniec 2018 r. wydał orzeczenie $\mathrm{w}$ sprawie ${ }^{89}$. Trybunał wyraził w nim wątpliwości co do zgodności nowego rozwiązania prawnego z niemiecką Ustawa zasadniczą (niem. Grundgesetz), jako że w przypadku małżeństw zawartych przez osoby będące poniżej 16. roku życia działa ono de facto z mocą wsteczną. Ponadto zdaniem Trybunału zgodnie z Ustawą zasadniczą ochronie podlegają wszystkie małżeństwa, także te zawarte za granicą. Odmowa skuteczności takich małżeństw następujacca automatycznie, w oderwaniu od konkretnego przypadku, godzi więc w konstytucyjne prawa jednostek. $\mathrm{Z}$ tych powodów Trybunał zawiesił postępowanie i skierował pytanie do Federalnego Trybunału Konstytucyjnego (niem. Bundesverfassungsgericht), aby orzekł on co do zgodności ustawy o zwalczaniu małżeństw dzieci z Ustawa zasadniczą ${ }^{90}$.

Zmiana prawa majaca na celu zwalczanie małżeństw dzieci została także wprowadzona w Szwecji. W kontekście najnowszej nowelizacji warto przybliżyć wcześniejsze zmiany szwedzkich przepisów odnoszacych się do zawarcia małżeństwa. Zanim wspomniane działania zostały podjęte, minimalny wiek zawarcia małżeństwa obowiązujący w Szwecji

${ }^{87}$ Ibidem, s. $430-431$.

${ }^{88}$ N. D e t h 1 o f f: Child Brides on The Move: Legal Responses to Culture Clashes. "International Journal of Law, Policy and The Family" 2018, vol. 32, s. 309.

${ }^{89}$ Postanowienie z 14 listopada 2018 r., XII ZB 292/16.

${ }^{90}$ Zapowiedziano, że orzeczenie w tej sprawie zostanie wydane do końca 2019 r. 
określony był na 18 lat. Istniała możliwość zawarcia małżeństwa przed skończeniem 18. roku życia, o ile były ku temu specjalne powody, a zgoda została wydana przez radę regionu (sv. länsstyrelse) ${ }^{91}$. Zgoda była zazwyczaj wydawana, gdy ukończenie 18 lat przez osobę zamierzająca zawrzeć małżeństwo miało nastąić wkrótce ${ }^{92}$, przyszła żona była w ciąży, a urodzenie dziecka pozamałżeńskiego wiązałoby się dla niej z poważnymi trudnościami w jej kręgu rodzinnym, kulturowym i religijnym ${ }^{93}$.

W 2004 r. wprowadzono zasadę, zgodnie z która prawem właściwym dla małżeństw zawieranych w Szwecji, przed szwedzkimi organami jest prawo szwedzkie. Określa ono nie tylko wymogi formalne zawarcia małżeństwa, ale także przesłanki materialnoprawne, w tym wymagany wiek ${ }^{94}$. Lex loci celebrationis matrimonii ma zastosowanie nie tylko wówczas, gdy małżeństwo jest zawierane przez obywateli szwedzkich czy osoby majace miejsce zwykłego pobytu na terytorium Szwecji, ale także gdy małżeństwo jest zawierane przez cudzoziemców. W tej ostatniej sytuacji, gdy nupturient nie jest obywatelem Szwecji, ani nie ma w tym państwie miejsca zwykłego pobytu, jego zdolność do zawarcia małżeństwa jest oceniana kumulatywnie w świetle prawa szwedzkiego i jego prawa personalnego, którym może być jego prawo ojczyste lub prawo państwa miejsca zwykłego pobytu, w zależności od jego wyboru ${ }^{95}$.

Dodatkowo, aby uniemożliwić obejście powyższej regulacji, małżeństwa zawarte za granica wbrew zakazowi zawarcia małżeństwa obowiazujacemu w prawie szwedzkim nie są uznawane za ważne w Szwecji, o ile choć jeden $\mathrm{z}$ małżonków miał w chwili zawarcia małżeństwa szwedzkie obywatelstwo lub miejsce zwykłego pobytu w Szwecji ${ }^{96}$. Co istotne, oceniane jest czy przeszkoda istniała w chwili zawarcia małżeństwa, a nie

${ }^{91}$ F. N o z a r i: The 1987 Swedish Marriage Code. Washington D.C. 1989, s. 10.

${ }^{92} \mathrm{Wg}$. danych z lat 2008-2010 w sumie 68 osób poniżej 18. roku życia wnioskowało o zgodę na zawarcie małżeństwa. Tylko $6 \mathrm{z}$ nich taką zgodę uzyskało, wszystkie miały ukończone 17 lat. Za: Summary of the Report of the Swedish Law Commission: Strengthened Protection against Forced and Child Marriages (Statens Offentliga Utredningar 2012:35), w: The Child's Interests in Conflict. The Intersections between Society, Family, Faith and Culture. Red. M. J ä n t e r ä - J a r e b o r g. Cambridge-AntwerpPortland 2016, s. 193.

${ }^{93}$ G. L a m b e r t z: Child Marriages and the Law - with Special Reference to Swedish Developments, w: The Child's Interests in Conflict. The Intersections between Society, Family, Faith and Culture. Red. M. J ä n t er ä - J a r e b o r g. Cambridge-Antwerp-Portland 2016, s. 99.

${ }^{94}$ Ibidem, s. 91.

${ }^{95}$ M. J ä n t e r ä - J a r e b o r g: Non-Recognition of Child..., s. 272.

${ }^{96}$ M. B o g d a n: Some critical comments on the new Swedish rules on non-recognition of foreign child marriages. "Journal of Private International Law" 2019, vol. 15, nr 2, s. 249. 
w chwili, w której ma nastąić jego uznanie ${ }^{97}$. Tym samym osiągnięcie przez małżonków wymaganego wieku w późniejszym czasie nie zmienia sytuacji prawnej małżeństwa ${ }^{98}$.

Najczęściej zakazem zawarcia małżeństwa obchodzonym przez zawarcie małżeństwa za granica był właśnie zakaz dotyczący minimalnego wieku wymaganego dla zawarcia małżeństwa ${ }^{99}$. Przewidziana została także wyjątkowa możliwość odstapienia od zasady nieuznawania małżeństwa zawartego za granica wbrew zakazowi zawarcia małżeństwa obowiązującemu w prawie szwedzkim. Mogło to nastapić, jeśli miały miejsce specjalne powody. Jako przykłady takich powodów regulacja prawna wymieniała przykładowo fakt, że związek ze Szwecja miał charakter formalny, podczas gdy związek z państwem, w którym małżeństwo zostało zawarte miał ścisły i realny charakter; że od zawarcia małżeństwa upłynęło dużo czasu, a małżonkowie trwali w przekonaniu, że zawarte przez nich małżeństwo jest ważne i skuteczne; oraz uznanie małżeństwa powinno nastąić ze względu na interes dziecka lub dzieci, które przyszyły na świat w tym małżeństwie. Jednocześnie wykluczona była możliwość odstąienia od nieuznania małżeństwa jedynie z powodu osiągnięcia przez małżonków 18. roku życia ${ }^{100}$.

Jeśli jednak w chwili zawarcia małżeństwa nie istniało powiązanie między Szwecja a małoletnim nupturientem, wówczas małżeństwo było uznawane przez szwedzkie władze, o ile zostało zawarte zgodnie z prawem właściwym, tj. prawem ojczystym lub prawem państwa miejsca stałego pobytu nupturientów. Dotyczyło to w przeważającej większości osób, które ubiegały się o azyl, gdyż przed przybyciem na terytorium Szwecji nie miały one żadnego powiązania z tym krajem ${ }^{101}$. Uznanie małżeństwa mogło zostać zablokowane jedynie przez powołanie się na sprzeczność ze szwedzkim porządkiem publicznym. Taka sytuacja była jednak traktowana jako wyjątkowa, podczas gdy generalną zasadą było uznawanie

${ }^{97} \mathrm{~S} . \mathrm{M} \mathrm{u} \mathrm{s} \mathrm{t}$ a s a a $\mathrm{r}$ i: The married child belongs to no one? Legal recognition of forced marriages and child marriages in the reuniting of families. "Child \& Family Law Quarterly" 2014, vol. 26, s. 268.

${ }_{98}$ Powyższą sytuację dobrze obrazuje sprawa, która trafiła w 2012 r. do szwedzkiego Wyższego Sądu Administracyjnego (szw. Högsta förvaltningsdomstolen). W orzeczeniu wydanym 14 marca 2012 r. (HFD 2438-11) sąd zdecydował o odmowie skuteczności małżeństwa zawartego w Palestynie przez kobietę, która nie miała ukończonych 18 lat w chwili zawarcia małżeństwa oraz miała w Szwecji miejsce stałego pobytu. Nie miało przy tym znaczenia, że ceremonia odbyła się 10 dni przed jej 18 urodzinami, i że w trakcie postępowania miała już ukończone 18 lat oraz była w ciąży ze swoim mężem.

${ }^{99}$ M. J ä n t e r ä - J a r e b o r g: Non-Recognition of Child..., s. 272.

${ }^{100}$ Ibidem, s. 273.

${ }^{101}$ M. B o g d a n: Some critical comments... s. 250. 
małżeństw, nawet jeśli zostały zawarte przez osobę, która nie ukończyła 18 roku życia ${ }^{102}$.

Kolejna nowelizacja prawa małżeńskiego została przeprowadzona w 2014 r. Zniesiono wówczas całkowicie możliwość zawarcia małżeństwa przez osoby poniżej 18. roku życia. Szwedzkie organy nie mają więc już kompetencji do wydawania zezwoleń na zawarcie małżeństwa przez osobę, która nie ukończyła 18 lat ${ }^{103}$. Ponadto do prawa karnego wprowadzono sankcję karną za wykorzystywanie swojej nadrzędnej pozycji lub stosowanie przymusu, aby zmusić kogoś do zawarcia małżeństwa wbrew jego woli ${ }^{104}$. Przepis ten nie obejmuje jednak swoim zakresem wszystkich małżeństw zawieranych przez osoby poniżej 18. roku życia, a jedynie te, które zostały zawarte przez nie wbrew ich woli ${ }^{105}$. Kwestią otwartą pozostaje to, jak należy rozumieć „zmuszenie kogoś do zawarcia małżeństwa wbrew jego woli" ${ }^{106}$. Co więcej, sankcja karna została przewidziana nie tylko za podejmowanie takich działań w Szwecji, ale także za granicą ${ }^{107}$, jeśli obejmują one zorganizowanie podróży do innego państwa, niebędącego miejscem zwykłego pobytu danej osoby, w celu zawarcia tam przez nią małżeństwa ${ }^{108}$.

6 grudnia 2018 r. przyjęto nowelizację ustawy o niektórych międzynarodowych stosunkach prawnych $\mathrm{w}$ zakresie małżeństwa i opieki ${ }^{109}$. Obecnie małżeństwo zawarte przez osobę, która w chwili jego zawarcia nie miała ukończonych 18 lat, nie zostanie uznane w Szwecji za ważne, bez względu na powiązanie małżonków ze Szwecją. Odstąpienie od tej

${ }_{102}$ M. J ä n t e r ä - J a r e b o r g: The Child in the Intersections between Society, Family, Faith and Culture, w: The Child's Interests in Conflict. The Intersections between Society, Family, Faith and Culture. Red. M. J ä n t e r ä - J a r e b o r g. CambridgeAntwerp-Portland 2016, s. 21.

${ }^{103}$ G. L a m b e r t z: Child Marriages..., s. 99.

${ }^{104}$ Kodeks karny (szw. Brottsbalken) z 21 grudnia 1962r., 1962:700, rozdział 4, 4c§.

${ }^{105}$ G. L a m b e r t z: Child Marriages..., s. 108.

${ }^{106} \mathrm{~W}$ przypadku małżeństw dzieci oraz małżeństw z przymusu najczęściej podkreśla się, że wszelkie formy wywierania presji są w sprzeczności z zasadą swobody zawarcia małżeństwa. W pkt 4 rezolucji nr 1468 Zgromadzenia Parlamentarnego Rady Europy z 2005 r. małżeństwa z przymusu zostały zdefiniowane jako „związek dwóch osób, z których przynajmniej jedna nie wyraziła pełnej i swobodnej zgody na zawarcie małżeństwa”. Wydaje się, że im niższy wiek, w którym dana osoba zawarła małżeństwo, tym więcej wątpliwości dotyczących tego, na ile wyrażona przez nią zgoda była pełna i swobodna.

${ }^{107}$ Kodeks karny (szw. Brottsbalken) z 21 grudnia 1962r., 1962:700, rozdział 4, 4d§.

${ }^{108}$ Informacja Greater protection against forced marriage and child marriage $\mathrm{z}$ oficjalnej strony rządu Szwecji https://www.regeringen.se/, opublikowana w czerwcu 2014 r. [dostęp 30.06.2019].

${ }^{109}$ Ustawa o niektórych międzynarodowych stosunkach prawnych w zakresie małżeństwa i opieki (sv. Lag om vissa internationella rättsförhållanden rörande äktenskap och förmynderskap) z 8 lipca 1904 r., 1904:26. 
zasady może nastąpić jedynie wyjątkowo, jeśli istnieją ku temu szczególne powody, a każdy z małżonków ma obecnie ukończone 18 lat. Powyższe rozwiązanie ma zastosowanie do wszystkich małżeństw zawartych po dacie wejścia w życie nowelizacji, tj. po 1 stycznia 2019 r, w tym również tych, które zostały zawarte za granica.

Warto przy tym zaznaczyć, że w prawie szwedzkim zakończenie bytu prawnego małżeństwa może nastąić jedynie przez śmierć jednego z małżonków albo przez rozwód ${ }^{110}$. W prawie szwedzkim nie istnieje mechanizm unieważnienia małżeństwa. Stąd też sankcja przewidziana w znowelizowanych przepisach oznacza nieważność z mocy prawa, która wywołuje skutki ex tunc, tak jakby małżeństwo nie zostało nigdy skutecznie zawarte. Małżeństwo zawarte przez osobę poniżej 18. roku życia nie wywołuje więc żadnych skutków alimentacyjnych ani spadkowych, nie obowiązuje także domniemanie dotyczące pochodzenia dziecka. Małżeństwo nie może też być przedmiotem rozwodu i nie jest przeszkodą dla zawarcia kolejnego małżeństwa. Jedyną możliwościa, żeby małżeństwo wywołało wspomniane skutki prawne w Szwecji jest jego ponowne zawarcie zgodnie z prawem szwedzkim, czyli po ukończeniu przez oboje nupturientów 18 lat. Wówczas jednak skutki takiego małżeństwa będa ex nunc ${ }^{111}$, czyli nie będą obejmować np. spraw majątkowych, które powstały przed zawarciem małżeństwa w Szwecji, czy też pochodzenia dzieci, które z tego związku już się urodziły.

Aby małżeństwo zostało uznane za nieważne z mocy prawa, nie jest przy tym konieczne istnienie jakiegokolwiek powiązania między małżonkami a Szwecją w chwili zawarcia małżeństwa. Nie ma także znaczenia, w jakim wieku małżonkowie sa obecnie. Tym samym, podobnie jak $\mathrm{w}$ przypadku rozwiązania niemieckiego, małżonkowie mogli w dobrej wierze zawrzeć małżeństwo zgodnie z prawem właściwym dla jego zawarcia, co pozwalało im oczekiwać, że ich małżeństwo zostanie uznane za ważne i skuteczne. Początkowo proponowano, aby małżeństwo było nieuznane jedynie wówczas, gdy małżonkowie mieli poniżej 18 lat w chwili wjazdu na terytorium Szwecji. Zrezygnowano jednak z tego pomysłu, jako że oznaczałoby to niejako wprowadzenie do prawa szwedzkiego normy kolizyjnej zbudowanej w oparciu o nowy łącznik, nieznany dotychczas w szwedzkim prawie małżeńskim.

${ }^{110}$ E. R y r s t e d t: Family and inheritance law, w: Swedish Legal System. Red. M. B o g d a n, Stockholm 2010, s. 246.

${ }^{111}$ M. J ä n t e r ä - J a r e b o r g: The Child in the Intersections..., s. 24. 


\section{Ocena nowych rozwiązań prawnych dotyczących małżeństw dzieci z punktu widzenia prawa prywatnego międzynarodowego}

Przedstawione zmiany $\mathrm{w}$ systemach prawnych wybranych państw europejskich, mimo że maja taki sam cel, jakim jest przeciwdziałanie małżeństwom dzieci, znacząco różnią się między sobą. Stąd też ich ocena z punktu widzenia prawa prywatnego międzynarodowego jest różna.

Zmiany prowadzace do podwyższenia wieku wymaganego dla zawarcia małżeństwa oraz wyeliminowania możliwości zawarcia małżeństwa mimo nieosiagnięcia tego wieku należy ocenić pozytywnie. Wyjątki dotyczące wymaganego wieku zawarcia małżeństwa często pozwalają na różne traktowanie w zależności od przynależności do różnych grup społecznych lub religijnych. Ponadto sama możliwość uzyskania zgody na zawarcie małżeństwa przez osobę, która nie ukończyła wymaganego wieku w praktyce mogła prowadzić do nacisków ze strony rodziny i bliskiego otoczenia na zawieranie związków nieformalnych oraz na prokreację w młodym wieku. Zawarcie małżeństwa pomimo nieosiąnięcia wymaganego wieku prowadzi najczęściej także do emancypacji danej osoby, co powoduje, że nie korzysta ona z ochrony, jaka prawo obejmuje dzieci ${ }^{112}$.

$\mathrm{Z}$ kolei na gruncie kolizyjnym wprowadzenie bezwzględnego limitu wieku wymaganego do zawarcia małżeństwa jest wyraźnym sygnałem, że państwo nie aprobuje zawierania małżeństw przez osoby niedojrza$\mathfrak{l e}^{113}$. Służy także wyeliminowaniu podwójnych standardów, w których państwo nie pozwala na zawarcie małżeństwa cudzoziemcom, których prawo personalne na to pozwala, mimo że we własnym systemie dopuszcza możliwość uzyskania zgody na zawarcie małżeństwa przez osoby, które także nie ukończyły wymaganego wieku.

Znacznie bardziej problematyczna jest ocena regulacji dotyczacych nieuznawania małżeństw zawartych za granica przez osoby, które nie osiąnęły wymaganego wieku. Omówione zmiany w przepisach niemieckich i szwedzkich zostały krytycznie ocenione przez niektórych przedstawicieli doktryny. ${ }^{114}$. Przede wszystkim zarzuca im się brak elastyczno-

${ }^{112}$ G. L a m b e r t z: Child marriages..., s. 101.

${ }^{113}$ Przykładowo informacja dotycząca motywów przyjęcia przepisów dotyczących małżeństw dzieci w Norwegii: Norway bans child marriages, opublikowana 25 lipca 2018 r. na oficjalnej stronie rządu Norwegii, https:/www.regjeringen.no/, [dostęp 30.06.2019].

${ }^{114}$ Wywiad z J. Basedowem opublikowany na stronie internetowej Instytutu Maxa Plancka Prawa Porównawczego i Prywatnego Międzynarodowego (niem. Max-Planck- 
ści. Ten sam cel może być realizowany z powodzeniem poprzez powołanie się na ogólną klauzulę porządku publicznego, której zastosowanie podlega każdorazowo odrębnej ocenie w kontekście wszystkich okoliczności sprawy. Punkt wyjścia niemieckiego ustawodawcy, tj. założenie, że zawarcie małżeństwa przez osobę nieletnia godzi w jej prawa również nie jest prawdziwe w każdym przypadku. Zwłaszcza w sytuacji, gdy do zawarcia małżeństwa doszło dawno i małżonkowie trwali w pożyciu przez ten czas. Odmówienie skuteczności lub unieważnienie małżeństwa w takiej sytuacji może pogorszyć sytuację małżonków oraz ich wspólnych dzieci.

Powoływanie się w tym celu na klauzulę porządku publicznego ma tę przewagę, że klauzula jest zawsze stosowana w konkretnej sprawie, nigdy abstrakcyjnie. Automatyczna odmowa skutków prawnych małżeństw zawartych za granica może natomiast naruszać prawa osób, które w założeniu ma chronić. Osoby te mogły działać w dobrej wierze, zgodnie z prawem właściwym oraz swoim prawem personalnym, a mimo to moga zostać pozbawione ochrony. Szczególnie dotkliwe byłoby nieuznanie skutków małżeństwa zawartego wiele lat wcześniej, które nastąiłoby w ramach postępowania alimentacyjnego lub spadkowego, diametralnie zmieniając sytuację prawną danej osoby.

Co prawda przepisy dotyczące nieuznawania małżeństw dzieci $\mathrm{w}$ większym lub mniejszym stopniu zostawiaja pewien margines swobody, gdyż od odmowy przyznania skutków prawnych można odstapić, jeśli istnieją ku temu „specjalne powody”. Ich istnienie oceniane jest ad causum, zazwyczaj gdy ważność małżeństwa stanowi kwestię wstępną dla innej kwestii głównej115. Tym samym powoływanie się na „specjalne powody" celem uznania małżeństwa zbliża to rozwiązanie do mechanizmu klauzuli porządku publicznego ${ }^{116}$. Jednak na jego niekorzyść przemawiaja dwie kwestie. Po pierwsze, w przypadku klauzuli porządku publicznego, będącej tradycyjnym mechanizmem prawa prywatnego międzynarodowego, w większości porządków prawnych istnieje utrwalona linia orzecznicza dotyczaca jej zastosowania. Zmniejsza to więc niepewność prawa. Natomiast w przypadku nowych rozwiązań prawnych dotyczących małżeństw dzieci wykładnia „specjalnych powodów”, które pozwalają na wyjątkowe przyznanie skutków prawnych takim małżeń-

-Institut für ausländisches und internationales Privatrecht), https://www.mpipriv.de/; M. B o g d a n, op. cit., s. 252-256.

115 Zob. M. J ä n t e r ä - J a r e b o r g: The Incidental Question of Private International Law, Formalised Same-Sex Relationships and Muslim Marriages, w: Essays in Honour of Michael Bogdan. Red. P. L i n d s k o u g et al. Lund 2013, s. 157-163.

116 Systemowo rozwiązania te można więc uznać za szczegółowe klauzule porządku publicznego. 
stwom będzie się dopiero kształtować. Obecnie więc jednostka ma ograniczone możliwości, aby przewidzieć czy jej małżeństwo zostanie uznane. Po drugie, zmieniaja one całkowicie optykę, która towarzyszy stosowaniu tradycyjnej klauzuli porządku publicznego. Podstawowym założeniem prawa prywatnego międzynarodowego jest, że prawo obce, jeśli jest związane ze stosunkiem prawnym, może być stosowane przez organy danego państwa. Wyjątek od tej zasady stanowi powołanie się na klauzule porząlku publicznego, w celu odmowy zastosowanie prawa obcego. Natomiast rozwiązania prawne dotyczące małżeństw dzieci jako zasadę przyjmuja nieuznawanie małżeństw zawartych za granica, od czego można wyjątkowo odstapić. Można więc odnieść wrażenie, że wypaczają podstawowe założenie prawa kolizyjnego.

Problematyczne jest też to, że decyzje dotyczące uznania małżeństwa zawartego za granicą maja w większości przypadków charakter raczej administracyjny niż sądowy. Z tego powodu decyzje takie podejmowane są przez różnego rodzaju organy wykonawcze, w tym przede wszystkim przez organy właściwe w sprawach imigracyjnych oraz do spraw rejestracji cudzoziemców. Bardzo często nie istnieją jednolite standardy odnoszące się do podejmowania decyzji przez te organy, przez co małżeństwo może być uznane przez niektóre $\mathrm{z}$ nich, podczas gdy przez inne nie ${ }^{117}$.

Poddając ocenie poszczególne rozwiązania dotyczące małżeństw dzieci, należy zauważyć, że przepisy holenderskie spełniają swój cel, unikając przy tym większości negatywnych skutków związanych $\mathrm{z}$ nieuznaniem małżeństwa ex tunc. Brak skutków prawnych małżeństwa dzieci zawartego za granica następuje bowiem jedynie czasowo, aż do ukończenia przez małżonków 18. roku życia.

Z kolei regulacja duńska ma istotna zaletę, która polega na tym, że ustawodawca wziął pod uwagę istnienie nakreślonych wcześniej różnic w prawie państw europejskich odnoszacych się do minimalnego wieku zawarcia małżeństwa. Problem małżeństw dzieci najczęściej kojarzy się z imigrantami spoza Europy. Tymczasem, zgodnie z prawem norweskim, szwedzkim czy niemieckim, odmowa skutków prawnych małżeństwa powinna nastąpić także w przypadku małżeństwa zawartego w Szkocji przez osoby, które ukończyły 16 lat lub w małżeństwa zawartego w Estonii za zgodą sądu przez osoby, które ukończyły 15 lat. W ramach UE niewątpliwie stanowiłoby to przeszkodę w swobodzie przepływu osób, stąd też duńskie przepisy wyraźnie stanowią, że nieuznanie małżeństwa ze względu na nieosiagnięcie minimalnego wieku przez nupturientów nie może nastąpić w przypadku obywateli państw należących do UE i EOG.

${ }^{117}$ K. J a n s e s n F r e d ri k s e n: The recognition of transnational..., s. 93. 
Takiego wyjątku nie przewiduja jednak pozostałe $\mathrm{z}$ omówionych regulacji, co z pewnością będzie powodowało problemy w praktyce ${ }^{118}$.

Szwedzka regulacja mająca na celu zwalczanie małżeństw dzieci jest z kilku powodów najbardziej radykalna. W porównaniu z nią rozwiązanie niemieckie wyróżnia dwie konsekwencje zawarcia małżeństwa przez osobę, która nie ukończyła 18 lat. Jeżeli małżeństwo zostało zawarte przez osobę mająca między 16 a 18 lat, wówczas jest ono ważnie zawarte, ale może zostać unieważnione. Jeśli natomiast małżeństwo zostało zawarte przez osobę, która nie ukończyła 16 lat, to nie wywołuje ono skutków prawnych tak, jakby nigdy nie zostało zawarte. Prawo szwedzkie przewiduje tylko jedna konsekwencję w postaci nieważności z mocy prawa. Dotyczy to wszystkich małżeństw zawartych przez osobę poniżej 18. roku życia. Tym samym granica wieku jest również wyższa niż w prawie niemieckim.

Niemiecka regulacja jest też bardziej elastyczna, jeśli chodzi o wyjątkowe uznanie małżeństwa zawartego przez osobę mającą między 16 a 18 lat. Pozwala bowiem małżonkowi po ukończeniu 18 roku życia zdecydować o bycie prawnym małżeństwa. Prawo szwedzkie nie daje takiej możliwości.

\section{Uwagi na tle prawa polskiego}

W prawie polskim wiek wymagany do zawarcia małżeństwa określony jest w art. $10 \S 1$ Kodeksu Rodzinnego i Opiekuńczego, który stanowi, że nie może zawrzeć małżeństwa osoba niemająca ukończonych 18 lat. Od powyższej zasady został ustanowiony wyjątek. Zgodnie z art. 10 $\S 1$ zd. 2 możliwe jest zawarcie małżeństwa przez kobietę, która ukończyła 16 lat, jeżeli zezwoli jej na to sąd opiekuńczy. Sąd może wydać takie zezwolenie, jeżeli występują ku temu ważne powodu i jeżeli z okoliczności wynika, że zawarcie małżeństwa będzie zgodne z dobrem założonej rodziny.

${ }^{118}$ Przykładem może być sprawa, którą zajmował się Wyższy Sąd Krajowy (niem. Oberlandesgericht) we Frankfurcie nad Menem (Az. 5 UF 97/19). Dotyczyła ona małżeństwa zawartego w Bułgarii, zgodnie z prawem tego państwa, przez kobietę, która miała 17 lat. Zgodnie z orzeczeniem wydanym 4 września 2019 r., sąd orzekł, że niemieckie władze muszą uznawać skutki prawne małżeństw zawartych w innych państwach członkowskich UE, nawet jeśli małżonkowie nie mieli w chwili zawarcia małżeństwa ukończonych 18 lat. 
Na gruncie kolizyjnoprawnym osiągnięcie minimalnego wieku uprawniające do zawarcia małżeństwa mieści się w pojęciu „możności zawarcia małżeństwa" ${ }^{119}$, dla której, zgodnie z art. 48 ustawy Prawo prywatne międzynarodowe ${ }^{120}$ właściwe jest prawo ojczyste nupturienta $\mathrm{z}$ chwili zawarcia małżeństwa. Prawo to może oczywiście określać dopuszczalny wiek zawarcia małżeństwa inaczej niż prawo polskie. Jak już było wspomniane, samo występowanie różnicy w tym zakresie nie uzasadnia zastosowania klauzuli porządku publicznego. Co do zasady powinno więc znaleźć zastosowanie prawo ojczyste cudzoziemca, nawet jeśli określa ono dla niego wiek wymagany dla zawarcia małżeństwa odmiennie niż prawo polskie ${ }^{121}$.

Powołanie się na klauzulę porządku publicznego w tej materii byłoby możliwe w dwóch przypadkach. Po pierwsze wówczas, gdy minimalny wiek wymagany dla zawarcia małżeństwa ustalony byłby tak wysoko, że ograniczałby prawo do zawarcia małżeństwa i założenia rodziny. W praktyce jednak wystapienie takie sytuacji jest mało prawdopodobne, gdyż państwa w swoim ustawodawstwach określają ten wiek na maksymalnie 22 lata $^{122}$.

Po drugie, zastosowanie klauzuli porządku publicznego jest uzasadnione, gdy prawo obce pozwala na zawarcie małżeństwa przez osobę, która nie ukończyła 15 lat. Zawarcie małżeństwa powoduje bowiem powstanie po stronie małżonków obowiązków określonych przez prawo, w tym, zgodnie z art. $23 \mathrm{KRO}$, obowiązku wspólnego pożycia, obejmujacego utrzymywanie relacji intymnych. Z kolei polskie prawo karne sankcjonuje podejmowanie czynności seksualnych z osobą poniżej 15 lat. Tym samym zawarcie małżeństwa przez osobę, która nie ukończyła 15 lat należy uznać za sprzeczne z podstawowymi zasadami polskiego porządku prawnego ${ }^{123}$.

Ostatnia kwestią wartą omówienia jest ewentualne wprowadzenie do prawa polskiego regulacji analogicznych do omówionych przepisów państw europejskich. Uważam, że warte rozważenia jest usunięcie z prawa rodzinnego możliwości zawarcia małżeństwa przez kobietę, któ-

${ }^{119}$ W. P o p i o ł e k: Zawarcie mał̇eństwa, w: System prawa prywatnego. Tom 20C. Prawo prywatne międzynarodowe. Red. M. P a z d a n. Warszawa 2015, s. 42.

${ }^{120}$ Ustawa z dnia 4 lutego 2011 r., Dz.U. 2011 nr 80 poz. 432.

${ }^{121}$ M. S o śn i a k, B. W a l a s z e k, E. W i e r z b o w s k i: Międzynarodowe prawo rodzinne. Wrocław-Warszawa-Kraków 1969, s. 37; M. P a z d a n: Prawo prywatne międzynarodowe. Warszawa 2012, s. 221.

${ }^{122}$ Taki minimalny wiek zawarcia małżeństwa przewidziany jest w prawie Chińskiej Republiki Ludowej dla mężczyzn. Kilka państw przewiduje wiek od 19 do 21 lat, natomiast zdecydowana większość - 18 lat. Dane z raportu UNICEF State of the World's Children przygotowanego w $2017 \mathrm{r}$.

${ }^{123}$ E. K a m a r a d: Zawarcie matżeństwa jako zagadnienie prawa rodzinnego, prawa prywatnego międzynarodowego i prawa konsularnego. Kraków 2019, s. 208-209. 
ra ukończyła 16 lat, ustalając tym samym bezwzględny wymóg ukończenia 18 lat przez osobę chcąca zawrzeć małżeństwo, niezależnie od jej płci. Obecne rozwiązanie ma charakter dyskryminujący, co zostało już wspomniane. Ponadto ustalenie minimalnego wieku uprawniającego do zawarcia małżeństwa na 18 lat mogłoby mieć pozytywny wpływ na stosowanie klauzuli porządku publicznego. Odmawiajac zastosowania prawa obcego, które przewiduje możliwość zawarcia małżeństwa przez osobę w wieku od 15 do 18 lat, sąd polski mógłby bowiem powołać się na to, że prawo polskie bezwzględnie wymaga ukończenia 18 lat, co oznacza, że konieczność osiagnięcia tego wieku jest podstawową zasadą polskiego porządku prawnego.

Nie widzę natomiast potrzeby wprowadzania do polskiego prawa kolizyjnego szczególnej klauzuli porządku publicznego odnoszącej się do małżeństw dzieci. Moim zdaniem generalna klauzula porządku publicznego wyrażona w art. 7 ustawy PPM jest wystarczajacca, aby zablokować możliwość zawierania małżeństw przez osoby, które nie osiagnęły określonego wieku, a także, w pewnym zakresie, uznawanie małżeństw dzieci zawartych w innym państwie. Z kolei istotna zaleta szczególnej klauzuli porządku publicznego, polegająca na tym, że jest ona wyrazem braku akceptacji dla małżeństw dzieci, w przypadku Polski ma dużo mniejsze znaczenie, gdyż w porównaniu z omawianymi państwami europejskimi, w Polsce zjawisko małżeństw dzieci występuje rzadziej.

\section{Podsumowanie}

Wprowadzanie powyższych zmian $\mathrm{w}$ prawie państw europejskich jest ściśle związane z kryzysem imigracyjnym ${ }^{124}$. Powodem takiego stanu rzeczy jest przede wszystkim to, że imigranci przybywają najczęściej z państw ${ }^{125}$, w których minimalny wiek uprawniający do zawarcia małżeństwa jest niższy niż w państwach europejskich, przez co małżeństwa dzieci występują znacznie częściej.

Co więcej, imigranci przybywający do Europy w przeważającej większości pochodzą z obszarów dotkniętych konfliktami zbrojnymi. Badania

${ }^{124}$ R. K o o l: Step Forward, or Forever Hold Your Peace: Penalising Forced Marriages in the Netherlands. "Netherlands Human Rights Quarterly" 2012, vol. 30, nr 4, s. 449.

${ }^{125}$ Największa imigracja z Syrii, Afganistanu, Iraku, Erytrei, Pakistanu, Nigerii, Somalii, Gambii, Bangladeszu, Senegalu. Dane z raportów opublikowanych przez organizację Human Rights Watch na jej stronie internetowej, https://www.hrw.org/. 
wykazuja, że w takich sytuacjach liczba małżeństw zawieranych przez dzieci znacznie się zwiększa ${ }^{126}$. Jest to częsta praktyka w obozach dla uchodźców. Zwłaszcza, gdy przebywanie w obozie nie jest sytuacją przejściowa, ale trwa dłuży czas ${ }^{127}$. Zawarcie małżeństwa, szczególnie przez nastoletnie dziewczęta, daje pewną ochronę przed przemoca oraz szansę na poprawę sytuacji ekonomicznej ${ }^{128}$. Ponadto w kontekście emigracji do Europy zawarcie małżeństwa potencjalnie pozwala na skorzystanie z prawa do łączenia rodzin. Osoba małoletnia ma większe szanse na otrzymanie statusu uchodźcy lub prawa do pobytu w państwie przyjmującym, a wraz z nią jej dorosły współmałżonek.

Początkowo główny problem polegał na tym, czy małżonkowie, z których jedno nie było pełnoletnie, powinni zostać umieszczeni w obozie dla uchodźców razem czy osobno. Zakwaterowanie ich razem oznaczałoby akceptację takich związków, natomiast rozdzielenie małżonków często miało na nich zły wpływ, włącznie z podejmowaniem przez nich prób samobójczych $\mathrm{z}$ tego powodu ${ }^{129}$. Z czasem jednak odmowa skutków małżeństw zawartych przez osoby, które nie osiągnęły wymaganego wieku następowała także w kontekście praw socjalnych oraz prawa do pobytu i prawa do łączenia rodzin.

Aby przeciwdziałać małżeństwom dzieci część państw europejskich w ostatnich latach wprowadziła zmiany w swoich porządkach prawnych. Prowadziły one do przyjęcia bezwzględnego limitu wieku, który musi być osiągnięty, aby możliwe było skuteczne zawarcie małżeństwa oraz do nieuznawania małżeństw zawartych za granicą przez osoby, które nie ukończyły wymaganego wieku, nawet jeśli małżeństwo zostało zawarte zgodnie z prawem obcym.

O ile zmiany dotyczące podwyższania limitu wieku wymaganego do zawarcia małżeństwa oraz usuwania prawnie dopuszczalnych wyjątków w tym zakresie należy ocenić pozytywnie, o tyle reguły dotyczące automatycznego nieuznawania małżeństw zawartych za granica przez osoby będące poniżej wymaganego wieku wydają się mieć więcej negatywnych, niż pozytywnych skutków.

${ }^{126}$ S. M e n z: Stateless and Child Marriage..., s. 528-529.

${ }^{127}$ J. d e S m e d t: Child Marriages in Rwandan Refugee Camps. "Journal of the International African Institute" 1998, vol. 68, nr 2, s. 217-219.

${ }^{128}$ S.A. B a r t e l s et al:: Making sense of child, early and forced marriage among Syrian refugee girls: a mixed methods study in Lebanon. "BMJ Global Health" 2018, nr 3, s. 4-10.

${ }^{129}$ Artykuł prasowy Migrant child brides put Europe in a spin opublikowany w serwisie internetowym BBC 30 września 2016 r., https://www.bbc.com/news/world-europe-37518289, [dostęp 30 czerwca 2019 r.] 